University of Louisville

ThinkIR: The University of Louisville's Institutional Repository

6-1948

\title{
A study of the social adjustment of twenty-eight children with epileptic seizures and predisposition to convulsions in the Louisville and Jefferson County Children's Home 1937-1948.
}

Elizabeth Whitcomb Brown

University of Louisville

Follow this and additional works at: https://ir.library.louisville.edu/etd

Part of the Social Work Commons

\section{Recommended Citation}

Brown, Elizabeth Whitcomb, "A study of the social adjustment of twenty-eight children with epileptic seizures and predisposition to convulsions in the Louisville and Jefferson County Children's Home 1937-1948." (1948). Electronic Theses and Dissertations. Paper 1877.

https://doi.org/10.18297/etd/1877

This Master's Thesis is brought to you for free and open access by ThinkIR: The University of Louisville's Institutional Repository. It has been accepted for inclusion in Electronic Theses and Dissertations by an authorized administrator of ThinkIR: The University of Louisville's Institutional Repository. This title appears here courtesy of the author, who has retained all other copyrights. For more information, please contact thinkir@louisville.edu. 
UNIVERSITY OF IOUISVILIE

\begin{abstract}
A STUDY OF THE SOCIAI ADJUSTMENT
OP TWENTY-EIGHT CHILDREN WITH FPILEPTIC SEIZURES

AND PREDISPOSITION TO CONVULSIONS IN THE

LOUISVILLE AND JEPFERSON COUNTY CHILDREN'S HONE

$1937-1948$
\end{abstract}

A Dissertation

submitted to the raculty

of the Raymond A. Kent school of social Work

In Partial Fultillment of the

Requirements for the Degree

or Master of selence in Social Work

By

ELIZABETH WHITCONB BROWN

1948 
NAME OF STUDENT: Elizabeth Whitcomb Brown

TITLE OF THESIS: A Study of the social Adjustment of Twenty-eight Children with Epileptic selzures and Predispoaition to Contulsions in the Louisvilie and Jefferson County Children's Home 1937-1948

APPROVED BY THE READING COMUITTEE COMPOSED OF THE FOLLOWING MEMBERS :

NAME OF DEAN: HOWOIIV. WIIliama

DATE: 7 feme 1948 


\section{ACKNOWLEDGMENT}

The writer wishes to acknowledge her gratitude to the staff of the Louisville and Jefferson County children's Home for their cooperation in placing material at her disposal, especially Mrs. Catherine Y. Fox, assitant Director and Suporviar or Case Work, and Misa Louise Madison, Supervisor of Records. 
Chapter

I. INTRODUCTION TO THE RESEARCH . . . . . . . . . . . I

Purpose of the study . . . . . . . . . . . 2

Scope and Method of the study .......... 6

The Louisvitle and Jefferson County Children's

Home... . . . . . . . . . . 11

II. SOME FACTS ABOUT EPILEPSY . . • . • . . . . . . . 16

III. CHARACTERISTICS OF THE GROUP . . . . . . . . . . . 23

Sex, Race, and Age at Commitment... .... . 24

Mental Development and School . . . . . . . . 25

Reason for Commitment... . . . . . . . 36

Broken Homes . . . . . . . . . . . . . . 39

Admissions to Children's Center . . . . . . 40

Siblings . . . . . . . . . . . . . . . . 45

History or seizures in the family . . . . . . 45

Classitication of Medical Diagnoses. . . . . . 46

Onset or Seizures and Behavior Problems . . . . 51

Medication and Control by Medication . . . . 53

IV. SOCIAL ADJUSTMENT OF THE GROUP . . . . . . . . . 57

Ad justment betore commitment to the Louisville and Jefferson County Children's Home..... Adjustment in the Institution and during

Commitment to the Agency ........... 59

Attitudes of the Family ............ . 64

Attitudes shown by others in the Agency . . . 65

Psychiatric Referrals ............. 68

Children Known to other Institutions...... . 69

Disposition upon Release from the Iouisville and Jefferson County Children's Home...... . 71

V. SUMMARY AND CONCLUSIONS . . . . . . . . . . . 74

Summary . . . . . . . . . . . . . . . . 75

Conclusions . . . . . . . . . . . . . . 78

APPENDIXES • • . . . . . . . . . . . . . . . . 81

A. RESULTS OF INTER-AGENCY COMMITTEE QUESTIONNAIRE ON EPILEPSY AS OF JULY I, 1947 . . . . . . . . . 82

B. INSTITUTIONS SURVEYED FOR EPILEPTIC CHILDREN, DECEMBER, 1947 . . . . . . . . . . . . 
C. SCHEDULE . . . . . . . . . . . . . 84-86

D. RESOURCES OF PSYCHIATRIC SERVICES USED BETORE

AND AFTER COMMITMENT . . . . . . . . . 87

BIBLIOGRAPHY . . . . . . . . . . . . . . 88 


\section{IIST OF TABLES}

Table

Page

1. Age of Commitment by sex and Race......... 24

2. Level of Intelligence in Louisville and Jefferson County Children's Home Population, General

Population, and Study Group.......... . 26

3. Relationship of Educational Achievement by Lerol of Intelligence and Grade Placement by Level of Intelligence and Educational Achievement . . .

4. Reasons for school Non-Attendance Any Time by Level of Intelligence... . . . . . . . . . . . 32

5. Reason for Commitment by sex and Race....... 37

6. Children from Broken Homes by Basis of commitment. 40

7. Admissions to Children's center before and after Commitment to Louisville and Jefferson County Children's Home. . . . . . . . . . . . . 41

8. Classification by Diagnosis or Children with Seizures and Predisposition to Epilepsy . . . .

9. Age of Onset of seizures and Behavior Problems by Age at Commitment . . . . . . . . . . . . .

10. Medication Used by Twenty-eight Children at Any one Timo

11. Number of Different Medications Used by Twenty-four Children . . . . . . . . . . . . . . .

12. Distribution of Unauthorized Absences by Twentyolght Children . . . . . . . . . . . . .

13. Children Known to Other Institutions Before and After Commitment to Louistille and Jefferson County children's Hom

14. Disposition of Fourteen Children upon Release from the Louisille and Jefferson County Children's Home 
CHAPTER I

INTRODUCTION TO THE RESEARCH 
CHAPTER I

INTRODUCTION TO THE RESEARCH

Purpose of the study

This study is an attempt to understand the social adjutment of epileptic children and those with a predisposition to convulsions in the Louigrille and Jefferson County Chilaren's Home. The viriter proposes to show what those chilaren were like, why they were committed to the agency, what their problems were, and what kind of an adjustment they were able to make within the agency. on July 1, 194\% the Inter-Agency committeo or the Health and Welfare council of the Loulsville community chest met to discuss the problem of the epileptie. This meeting was called at the request or one member, Mrs. Grace B. Caswe1l, Chief social Worker or Nichols Veterans Administration Hospital. Mra. Caswell stated that they were much concerned at Nichols about what was happening to the epilepties.

The Inter-Ageney committee is a sanding committeo or the Health and Welrare Council of the community chest. It 1 s one or the committees of the family Welfare comittee

Minutes, Inter-Agenoy Comittee, Health and Welfare Council, Louistille Community Chost, July $1,1947, p .1$. 
and is composed primarily or representatives of the caseworking, or ramily and child welfare, agencies in Louisille and Jefferson county. The members of the committee were concerned about the problems of omployment and rocational training for the older epileptio as well as the problems or the eplleptie child; there was the problem also of securing information on the number or epiloptics in Louisville and Jefferson county. In order to study possibilities and approaches to the problems of the epileptic, a sub-comititeo was appointed. It was composed or the Iollowing members: Mrs. Grace B. Caswell, Mr. Darid Dobson, Mrs. Catherine Richardson, and Mrs. Cora $\mathrm{E}$. 1 Lucas.

The sub-Comittee of the Inter-Ageney Committee met and planned a questionnaire which reaulted in a summary or casea reported by twenty-fire agencies as of July 1, 1947. These resulta were presented at the second meoting or the InterAgeney Committee on september $4,1947$.

Dr. James Rogers, who had deen in charge or the Neurology Clinie at Loulsville General Hospital Irom July, 1942 through July, 1946, was present at the september meeting of the Inter-Agency committee. He diseused the medical treatment or epileptics and presented his own observations based on his work with patients who had attended Neurology Clinie at Louisille

\footnotetext{
Ibid., September 4, 1947, p. 1 . See Appendix A, p. 82 .
} 
General Hospital during the period he supervised. 1 Dr. Ephraim Roseman, who succeodea Dr. Rogers as Head of the Neurology Clinie at Loulsville General Hospital, was present at the meeting and gave further information on the subject of opileptics. He mentioned the two national organizations, Ameriean Epilepsy League, Inc., and the National Association to Control Epilepay, which were doing a great deal to help the cause of the epileptic by distributing information and encouraging research.

It was pointed out that there was a need to educate the public as well as the epileptic. The social angles or the epileptic's problems were discuseed. Dr. Ethel H. O'Brien, paychiatrist for the Jeffergon County Jurenile Court and the Louisville and Jefferson County Children's Home, stressed the need for a special place for some children with opilepsy. Sho stated that there were a number or such children at Ormaby Village who did not fit in with the others in the institution. They did not have the type of personality suitable for institutions; they had a tremendous amount of irritability. There was discussion as to the desirability or placing such children in a special institution or mental sanatorium. The committer decided that the sub-committeo would consider whether other phases of the problem should be otudied.

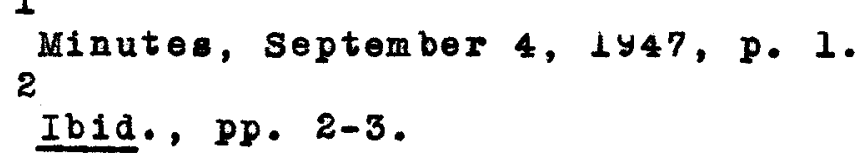


The Sub-Committeo or the Inter-Agency Committee met on october 20, 1947 to discuss the proposed study or epileptics. Members present were Mrs. Louis seelbach, presiding, Mrs. Irvin Abell, Jr., Mrs. Grace Caswell, Mrs. Cora Lucas, Dr. Ephraim Roseman, and Mrs. Louise R. Wood, secretary. At this meeting Dr. Roseman reported that Mr. Story Witten, state supervisor or the Physical Reatoration service ol the state Vocational Rohabilitation Department, might start a special program ror opileptics which would lnclude a clinte and rocational train1ng. The social service history of each case would be studid. Dr. Roseman atated that the rirst problem or the epileptic was modical care and the second was social adjutment, ineluding employment. He further stated that one of the most important needs to be met was educating the schools to keep epileptic children in school. As to the work of the committee, he stated that he thought the first joo was publicity and oducation but he advised waiting for the proposed clinic to open to present an opportunity ror extensive publicity. Mrs. caswell reported that some of the students rrom the Kent school of Social Work, University or Loulsville, might be interested in a study of Jefferson county. She had poken to Miss Hathilda Mathisen, faculty member of the Kent sehool, about the committee's interest. Miss Mathisen was oupervising four medical social work students, each or whom might be interested in the study as a thesis, if each could take a separate part or the problem of epilepsy.

1

Minutes, Sub-committee or Inter-Agency Committee, october 20,1947 . 
It was as a result of the foregoing committee activities and interests that the decision was reached and plans were made with the Kent school to permit the four Kent school medical social work students to mare separate studies as theses in partial fulfildment toward the requirements ror the degree of Master or seience in Social Work. The areas decided upon were: the chila in the community, the child in the ingtitution, the veteran, and vocational rehabilitation. This atudy has to do with the second namedield, the child in the institution.

Scope and Method of the study

The original scope or this study was to include children up to and including gixteen wo had convulsions or soizures and who were living in institutions in Louisville or Jefferson County. As noted in the results from the InterAgency Committee Questionnaire on Epileptics as of July 1 , 1

1947, Louisville and Jefferson County Children's Home reported lis cases and st. Vincent orphanago reported 2 cases. Although the writer rather expected to lind the majority of cases at the Louisille and Jefferson County Children's Home, sho did expect to locate additional cases at other institutions over a period or rive or ten jears. With this approach in mind, all children's institutions as listed in the Directory of social

1

See Appendix A, p. 82 . 
Agencies for Loulsille and Jefferson county, of the Health and Welfare Council of the Louisville commity chest, plus central state Hospital, Lakeland, Kentucky, were approached. In this survey or sixteen institutions the findings were surprisingly meager. One case was reported by $s t$. Joseph's Orphanage, and 2 cases were reported by st. Vincent's Orphanage. A preliminary survey showed 13 cases at the Louisville and Jefferson County Children's Home with a possibility of more upon turther investigation. one of the interesting features of this original survey was the fact that nearly all of those institutions who reported no cases at all were of the opinion that the $y$ had never had an epileptic child in their institution, one or the Catholic sister contacted stated that she had never encountered a Negro epileptic child in all the many years she had worked with children. In making this survey the person usualiy approached was the superintendent, someone in charge of the children, or someone who had been connected with the ingtitution for a period of time long enough to be familiar with the situation. In several eases it was noted that the institutions stressed their rigid physical examination upon entrance, and they stated that no epileptic child would have been accepted. Central state Hospital reported no cases or children from Jefferson County at the time of inquiry. Due to their method of tiling only active cases by diagnosis they were unable to make accessible the records or rormer, inactive cases.

Soe Appondix B, p. 83 . 
The 1 case reported by St. Josephis Orphanage proved to be child later commitred to Louisville and Jefferson County children's Home and included in their count. When it became apparent that only 2 cases had been located that were unknown to Louisrille and Jefferson County Children's Home, the writer Ielt justified in altering the original seope of the study from children living in institutions in Louisville and Jefferson County to one agency, namely, the Louisville and Jefferson County Children!s Home. In this way, tho study could be expanded to include the entire period of commitment to the Louistille and Jefferson County Children's Home, instead of merely the time when the child was living in the institution proper. Since the program of the Louisvilde and Jefferson County Children's Home incluaes much beyond the actual institutional lire at ormsby Village and Ridgewood, it was relt that the otudy would be or greater value with the change or focus. Many or the waras or the Louistille and Jefferson County Chilaren's Home are placed in boaraing or roster homes, and many are placed in their own nome or with relatives. As the ultimate goal of the institution is to return the child to the commuity and society, and to his own home ir that is possible, this study or epileptic children in the Louisville and Jefferson County children's Home is an attempt to show how these children responded to their total period or commitment, that is, how they adjusted to their various placements in the community and in the institution. 
Because it was believed that for most cbildren with epilepsy the crippling effect is social and notphysical, this study was concerned with the social adjusment of children with opileptic seizures and predisposition to convulsions in the Louisville and Jefferson County Children's Fome. The study includes 28 cases over an eleven year period trom March, 1937 through April, 1948. The method used was both the statistical approach and the case study method.

The primary source of information was the case record of each ehild. Each case record contained three separate sections: (1) reports, including medical, psychological, psychiatric, school, and conduct reports; (2) correspondence section, including letters or correspondence, notes, interoffice memos, council and conrerence notes, change of status reports, commitment and release papers, and other miscellaneous items; and (3) social service record, including the social worker's "running record" and also the court summary, recommendations to the Board, placement ana transier summaries, and Board reports. As previousiy stated, the primary source of intormation was from these records. In several instances, where the social service record was not up to date, the writer discussed the case with the social worker to rill in the gap. As to case finding, the agency had compiled a list of epileptic children in July, 1947 in response to the Questionnaire 
sent out by the Inter-Agency comittee. Ihis list was available as a starting point. The agency did not maintain a record by medical diagnosis or the children committed. Therefore, it was necessary to depend upon the memory or the various workers tor locating the cases to be studied. Another aid to case finding was referral to a medication list maintained by the agency. These lists were available for the period february 8, 1944 through Mareh 18, 1948, with some gaps throughout. Dr. Ethel H. O'Brien, psychiatrist for the Juvenile Court and the Louistille and Jefferson County Children's Home, was able to ouggest the names of several children who showed a predisposition to epilepsy. Inasmuch as the original 13 cases as reported by the agency in July, ly47 included children with a predisposition to epilepsy, these vere made a part of the present study. Had time permitted, the writer would have included aditional children with a predisposition to convulsions, for it is felt that their number has not been exhausted. In order to better understand the group of children in this study and to see what sort or an adjustment they were able to make during their commitment to the Louisville and Jefferson county Children's Home, a schedule was prepared. The Iollowing various types of information were secured: sex, race, age when committed, diagnosis, reason ror commitment, age at onset of

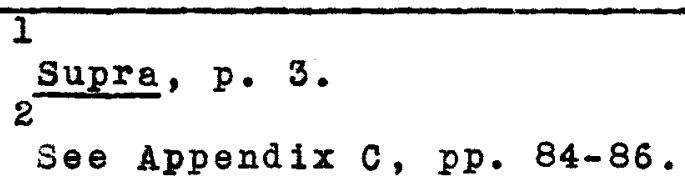


seizures or behavior problems, frequency of attaeks, attitudes or the child and his tamily toward epilepsy, types of behavior the child exhibited berore commitment and how handled, siblings, history or seizures in the ramily, how the child adjusted in the institution, medication, control or seizures, mental development, school achievement and placement, psychiatric rererrals, disposition upon release, and reason for release.

These data were treated statiatically and apper in tables to show various phases, in the child's social adjustent. The case study method was used to illustrate material which did not lend itself to statistical analysis. The findings of this study are presented in chapters III and IV.

\section{The Louisville and Jefferson County Children's $\operatorname{Hom} \theta$}

Thorough studies or the Louisville and Jefferson County children's Home have been made by such organizations as the Child Welfare League of America, the Russell sage Foundation, and the osborne Association. The changes in philosophy of child care in relation to apecific problems which are common to all institutions that have to deal with delinquent and dependent children have been traced in a previous study by 1

Sherrill. The present study is not intended in any way to

Helen H. Sherrill, "Changing fhilogophy or Child Care in the Louisville and Jefterson County Children's Home (1854-1943)," Unpublished Master's Thesis, Graduate Division of Social Adminiatration, Jniversity of Louisville, 1944. 
duplicate those works. A few racts about the Louisille and Jetterson County Children's Home, however, may bo helprul in understanding the child in his environment.

$$
\text { Something of the growth of the institution may be }
$$

seen Irom the changes in its name. It dates back to ciril

War times when it was created as "The Louigville House of

Refuge." About twenty years later the name was changed to "The Loüisille Industrial school or Rerorm." In 1920, when it was consolidated with the Jefferson County Parental Home, it became "The Louisville and Jefferson County Children's Home." This name still designates the agency as a wole, but the more informal names "Ormsby Villagen and "Ridgewood" are used respectively for the two institutional divisions for the white and negro children.

The Louisville and Jefferson county Children's Home is a public ageney supported jointly by the city of Loulsille and Jefferson County. All children under care have beon committed through the Jefrerson county Juvenile court. In accordance with the change in thinking as to the best type of care tor aelinquent and dependent children, there has been an increasing tendency to place children in toster homes, or wherever posible to keep them in their own homes.

Margeretta Weber, Working with Dependent and De-
linquent Children in the Same Inatitution (Anchorage, Kentucky:
Ormoby Village Press, 1935), p. l.
Sherrill, op. cit., p. 31.


Begides the two institutions, Ormsby Village and Ridgewood, the Loulstille and Jefferson County Children's Home also has charge or the children's center, formerly called the Detention Home, and Sunshine Lodge which is an adjunct of the children's center. here are recelved for temporary care, pending rinal disposition by the Jurenile Court, the dependent, neglected, and delinquent children of Jefferson County. The center is used for the older children, and Sunshine Lodge is used for the younger children, oelow the age or ten. However, all children are first cleared through the center. The Iunction of the Children's center is best described as a threerold one. It is a detention home for a jl juveniles of Jefferson County awaiting hearing by the Jurenile court. Some may be committed to the Louisville and Jerferson County Children's Home and some may not be; some may already be wards or the agency. (2) It is a receiving home tor all children committed by the Juvenile court to the Louisville and Jefferson County Children's Home. These children remain in the Chilaren's center until. plans are formulated ror them as to their placement, either at the institution, ormsby village or Ridgewood, in a toster home, in their own home, or with

1

Personal interview with Mr. William H. Pyne, Assistant superintendent, Louisville and Jerferson county Children's Home and supervisor of the chilaren's center, May, 1948. 
relatives. (3) It is a temporary abode for Louisville and Jefferson County Children's Home wards between trangfers and placements, while receiving special care, study or treatment such as medical, psychological, psychiatric, and case work service, or ror any other special reason which the agency might feel was noeded for the child.

The Social Service Department is a vital part of the Louisville and Jefferson County Children's Home. It has contact with the child as soon as he is committed by the Jurenile Court to the Louisville and Jefferson County Children's Home. Until approximately two years ago, a member of the social Service Department participated in scheduled conferences at the Juvenile Court where the decision was made as to whether or not the child should be recommended for commitment. This practice has been discontinued on a routine basis, howerer, and conterences are now made only by appointment. It is the hope of the agency that these regularly scheduled conferences will be resumed.

As soon as a child is committed to the agoney, a social worker is assigned to him. This contact is begun while he is still at the children's center and continues during his entire period or commitment, or until the agency releases him. Case work service is given to every ward of the Louisville and

1

Personal interview with Mrs. Catherine Y. Fox, Assistant Director and Supervisor or Case Work, Louistille and Jefferson County Children's Home, May, 1948. 
Jefrerson County Children's Home. The initial study or the child is begun while he is still at the center. He is given a physical examination and tested by the Psychology Department. Where indicated, psychiatric service is arailable. The social worker has the use or these reporta with possible recommendetions, which help in rormulating plans ror the child. His problems are considered rrom every angle in tho hope of efrecting the kind of placement which w11l be most helpful and desirable tor him. His interests and abilities are discorered, and he is given some interpretation of the institution it that is to ve his placement. Relationship with the child by the social worker is meintained throughout his entire commitment.

The most impressive thing observed by Mrg. sherrill in her study was the manner in which each child was considered as an individual Irom the time or commitment until his release.

Ormsby Village and Ridgewood are built on the cottage plan. The open system without confining walls is a feature of the "campus," as the children generally speak of the Village. There is no segregation or dependents and delinquents. The pohiatrist tor the Jurenile court, Dr. Ethel H. O'Brien, is also the paychiatrist for the Louisilie and Jelferson County Children's Home. Thus she is active on many cases and ramiliar with some of their problems before they are actually committed to the Home.

sherrill, ㅇp. cit., p. 18 . 
CHAPTER II

SOME FACTS ABOUT EPIIEPSY 
This chapter will attempt to sot rorth briefly some of the facts about epilepsy. First, what is epilepsy?

In the last two decades, older concepts of the nature and prigin of these paroxysms have crumbled under the discoveries and contributions or neuro-pathologists, neurosurgeons, biochemists, physiologists, and physicians, who now consider these seizures to be not a disease, but a symptom of underlying pathology. Convulsive seizures are so infinitely variable in character and incidence and generally so hidden in origin that they have deried attempts at definition. Because of this, the name nepilepsy" is considered by many authorities to be an inaccurate and underirable term. It has been suggested that "parorysmal disorders," "conpulsive state," or ncontulsive seizures," be used instead.

Lennox, who is considered by many to be one or the foremost authorities on epilepsy, believes the word "epilepsy" should not be opposed but that the public should be educated to a sane and scientific attitude toward it. He suggests the use of the word "seizures," which is synonymous with "epilepsy" or "fits." Another descriptive term is "cerebral (brain) dysihythmia (disordered rhythm)."

$$
2
$$

1

The Eplleptic child in Illinois (IIlinois Commission for Handicapped Children, June 1943), p. 9 . 2

William G. Lennox, Science and Seizures (2d Edition; Now York: Harper and Brotners, 1946), pp. 18-19. 
The three kinds or seizures are described by Yahraes

in the following words:

1. Grand MaI

This "great illness" affects more persons than other types of epileptic seizures. During a grand mal attack, the patient loses consciousness, his muscles tighten, and he ralls. He may cry out or groan, although he does not remember pain. Saliva appears on his lips. His face may be tirat a usky and then pale. He twitches violentig for a minute or two--it seems much longer to the worried bystander. Usually in a minutes he lies relaxed. Then he may sleep heavily ror hours, or he may get up but reel dull for a short period.

2. Petit Mal (pykno-epilepsy)

seizures are much more rrequent in this "small illness" but are often orerlooked because they last only a rew seconds. Usualiy there is a rhythmic twitching or eyelids or eyebrows. lihe patient rarely falls.

Dr. Pracy Putnam gives this account of petit mal attack: "The patient was sitring calmly in the orfice, discussing his symptoms. He stopped in the middle or a sentence, stared vacantly, blinked, ana went on with what he was aying, only slightly contused." Parents otten disregard petit mat attacks in a child, supposing that eventually they will disappear. Usually they do. However, out or a large group atudied, one out or every three patients with petit mal later develop grand mal.

3. Psychomotor

This is the most difricult to diagnose because the attacks vary greatiy from one patient to another and because mild forms may look like petit mal and severe forms like grand mal. The name indicates that a psychic disturbance is the principal feature of the attacks. This type is intrequently found.

In a psychomotor seizure the patient is amnesic; that is, he may appear to be conscious, although afterward he does not remember anything that happened. Most such attacks last only a few minutes but with a few patients they continue longer. Patients have even gone

1

Herbert Yahraes, Ipilepsy--The Ghost is out of the Closet, Public Affairs Pamphlet No. 98 (New York: Public Affairs Committee, Inc., 1944), pp. 18-20. 
to a strange city without knowing what they were doing. The paychomotor seizure may appear to be only a temper tantrum or a period of queer bohavior--as in the case of a man who would wander around the room pulling down pictures and throwing books on the floor. When such episodes begin abruptly, are contrary to the person's ordinary character, and are not remembered by the patient, they are suggestive or epilepsy. In many cases it is hard Ior parents and asociates to believe that the patient's behavior is caused by anything but a "mean streak," But evidence that it is caused by a form or epilepsy can be shown by the electroencephalograph, or by the alleviation of such attacks following medical treatment.

All types or seizures may be so mild as to be hardiy discernible. A paychic or psychomotor seizure may manitest itselr as a period of sharply altered disposition, or of an aggreasive, antisocial act which the person cannot account for. Some "behavior problem" children are of this type. The borderline between paychic seizures and other disorders or mind or conduct is not sharply drawn. The presence also of petit mal or grand mal attacks and the distinctive electrical record of the brain clasaities the acts as epi1 leptic.

As to causes, Dr. Lennox states that in about onefourth or the cases some injury to the orain is at raut-injury resulting from a serere blow, encephalitis, meningitis, a tumor, or hardening or the brain arteries. The more usual cause is an inherent tendency or predisposition to seizures which was present at birth. Seizures may also result from 
disorders of body function such as the great lowering of the blood sugar, or some unpleasant or territying experiences may bring an underlying tondency to the fore.

An aid in diagnosis and treatment is the electroencephalograph, an ingtrument for recording the electrical currents or waves of the brain. The electroencephalogram (electric brain record) is commonif called E.E.G. or "brain wave." The electroencephalogram helps in differentiating epilepsy from fainting or hysteria, in locating brain injuries or tumors, in indicating the seriousness of the case, in suggesting the best drug to be used, and in following the success of the treatment.

The three most commonly used drugs at the present time are dilantin, used for grand mal and psychomotor seizures; phonobarbital, aloo used for grand mal and psychomotor opllepsy; and tridione, used for potit mal epilepsy. The last named drug cures completely approximately 30 per cent of petit mal eases, helps 30 per cent, and is of no value at all to another 30 per cent. Tridione is a convulsant, and if the patient has a combination of grand mal and petit mal it will cause convulsions of the grand mal type. Therefore, it is necessary first to control the grand

Lennox, The Epileptic--Who He Is-What He Can Do
(Chicago: American Epilepsy League, Inc., undated), p. 2 .
2
Ibid., p. 3.


mal seizures (by dilantin or phenobarbital) and then to use the tridione for the petit mal.

No general census of the number or persons having seizures is arailable either tor the United states or any other country. Due to the nature or the problem, it does not lend itselr readily to statistical study. It is orten conceled for fear of social stigma. Many suffering from the disorder do not seer medical treatment, believing it to be incurable. Or, the seizures may be so mila that they are not recognized for what they are. For these reasons, most estimates made as to the incidence of seizures are too low. Nevertheless, Dr. Lennox estimates that there are at least 500,000 persons in the United states who are or have been subject to seizures. This is about equat to the number having active tuberculosis or diabotes. It is, thererore, a very important disorder. And when one considers that ror every person who has seizures, there are about twenty who have a predisposition to it, its importance is multiplied. Dr. Roseman, of Louisville General Hospital, estimates that Kentucky has 30,000 epileptics, of whom 20,000 are below the age ot sixteen.

Lecture by Dr. Ephraim Roseman to a class of the Kent school of Social Work, Jnivergity or Iouisville, April 20 , 1948 .

2

The Eplleptic Child in Illinois, p. 16.

Lennox, Science and Seizures, p. 21. 4

Lecture by Dr. Roseman, April 20, 1948. 
Dr. Lennox states that peculiarities of personality or behavior are almost the rule among institutional epileptics, while they are the exception among clinic or private petients. There may be a "Dr. Jekyll and Mr. Hyden type of personality, cheertul and cooperative one day, the next day antagonistic, resiotive, irritable, or moody. In otner patients, however, there are constant and apparently Iixed characteristics or stubbornness, Loquacity, persistent "one trackn ideas, petty bodily symptoms, and complaints. Some call this the "epileptic personality." Dr. Lennox believes that these unpleasant traits are found but rarely in intelligent patients who have received proper psychological treatment from the beginning. He believes these traits of instability and hypochondriasis are not limited to epileptics but are symptoms round in any chronic 1 illness.

To correct some or the common fallacies about epilepsy, 2

these counter statements are suggested by Lennox:

The tendency is for seizures to get better with the years rather than worse. Mental deterioration is not a necessary or even usual acoompaniment of epilepsy. It is better to have "truen epilepsy rather than so-calied "symptomatic" epilepsy. Activity of body and mind and not "complete rest" is the best treatment for most patients. The great majority or patients, perhapa 75 per cent, can be rid or three-fourths or their seizures and meny are completely well with careful following of experienced medical adice. Epilepsy is not a complete mystery. The cause is a well known as the cause of diabetes or obesity. Finally, continued research should uncorer new methods of treatment.

\footnotetext{
Lennox, The Epileptic Patient and the Nurse (Boston: American Epilepay League, Inc.. undated), pp. 12-13. 2 Ibia.
} 
CHAPTER III

CHARACTERISTICS OF THE GROUP 
CHAPTER III

\section{CHARACTERISTICS OF THE GROUP}

\section{Sex, Race, and Age at Commitment}

Twenty-eight cases were studied. As shown in

Table I, the children ranged in age from 6 to 16 years at the time of their commitment. There was a falry eren distribution in age, with the largest number of commitments (8) at the age of 13. Four children each were committed at the ages of 14 and 6 years. The remaining 12 children were distributed throughout the other years in smaller numbers. It is interesting to note that the majority of children were committed during adolescence.

TABLE 1

AGE OF COMMITMENT BY SEX AND RACE

\begin{tabular}{|c|c|c|c|c|c|c|c|}
\hline \multirow{3}{*}{$\begin{array}{l}\text { Age at } \\
\text { Commit- } \\
\text { ment }\end{array}$} & \multicolumn{6}{|c|}{ Sex } & \multirow[b]{3}{*}{ Total } \\
\hline & \multicolumn{3}{|c|}{ Hale } & \multicolumn{3}{|c|}{ Female } & \\
\hline & White & Negro & Total & White & Negro & Total & \\
\hline 6 & 2 & - & 2 & 2 & - & 2 & 4 \\
\hline 7 & 1 & - & 1 & - & - & - & $i$ \\
\hline 8 & - & - & - & - & - & - & - \\
\hline 9 & 3 & - & 3 & - & - & - & 3 \\
\hline 10 & 1 & 1 & 2 & - & - & - & 2 \\
\hline 11 & 2 & - & 2 & - & - & - & 2 \\
\hline 12 & - & - & - & - & 1 & 1 & 1 \\
\hline 13 & 5 & 2 & 7 & 1 & - & 1 & 8 \\
\hline 14 & 3 & 1 & 4 & - & - & - & 4 \\
\hline 15 & 1 & - & 1 & 1 & - & 1 & 2 \\
\hline 16 & - & 1 & 1 & - & - & - & $I$ \\
\hline Total & 18 & 5 & 23 & 4 & 1 & 5 & 28 \\
\hline
\end{tabular}


By sex, there was an unequal distribution. Twentythree or the 28 children were males. of the males, there were more than three times as many white boys (18) as negro boys (5) in the group. Of the 5 girls included in the study, 4 were white and 1 was negro. These findings are interesting but hardfy significant, in view of the small number of cases studied. They do not seem to go along with the statement that nincidence of seizures is about the same in the two 1

sexes." It is very likely that the distribution would have become more balanced as the number increased, but that is only a conjecture.

Mental Derelopment and School

Table 2 shows the distribution in percentage of children by level of intelligence. This is compared with the level or intelligence or a group or chilaren committed to the Louigville and Jefterson County Chilaren's Home over a year's period or time and with the general population.

The classifieations used tor level or intelligence are those used by the Psychology Department of the Louisville and Jefferson County Children's Home. I.Q. soores corresponding to these classitications are as tollows: very superior, 140 and above; superior, 120 - 139; bright normal, 110 - 119; average, 90 - 109; dull normal, 80 - 89; borderline, 70 - 79; mental defective, below 70 . 
TABLE 2

LEVEL OF INTELLIGENCE IN LOUISVILLE AND JEFFERSON COUNTY CHILDREN'S HOME POPULATION, GENERAL POPULATION, AND STUDY GROUP

\begin{tabular}{|c|c|c|c|}
\hline $\begin{array}{l}\text { Ievel of } \\
\text { Intelligence } \\
\text { (1) }\end{array}$ & $\begin{array}{l}\text { Per cent } \\
\text { General } \\
\text { Populationa } \\
\text { (2) }\end{array}$ & $\begin{array}{l}\text { Per cent } \\
\text { L\&JCCH } \\
\text { Commitments } \\
\qquad(3) \\
\end{array}$ & $\begin{array}{l}\text { Per cent } \\
\text { Study } \\
\text { Group } \\
\text { (4) }\end{array}$ \\
\hline Very superior & 0.25 & - & - \\
\hline superior & 6.75 & 1.30 & 3.60 \\
\hline Bright Normal & 13.00 & 5.50 & - \\
\hline Average & 60.00 & 31.10 & 35.70 \\
\hline Dull Normal & 13.00 & 25.30 & 32.20 \\
\hline Borderline & 6.00 & 25.30 & 21.40 \\
\hline Hental Defective & 1.00 & 11.50 & 7.10 \\
\hline
\end{tabular}

a

Figures trom Florence M. Teagarden, Child Psychology for Professional Workers (rev. ed.; New York: Prentice-Hall, Inc., (946), p. 393.

b

Figures compiled from computations taken trom Pauline Klinger, Second Annual Report, Paychology Department, L\&JCCH, Anchorage, Kentucky, JuIy $I, I y 44-J u 1 y 1,1945$. Pages unnumbered.

The rigures in column is were compiled uy the writer from computations secured on all new commitments to Louisville and Jefferson County Children's Home for the year July 1,1944 to July 1, 1945. The percentages used in the report were derived Irom verbal I.Q. scores. The figures in column 2 , 
pertaining to the general population, were taken rrom Teagarden's Child Poychology tor Professional Workers. Miss Teagarden stated that the figures were appoximations derived from many sources and were fairly familiar and in common use. The percentages for the 28 children studied by the writer appear in column 4. Again, due to the small number or cases studied, it is not felt that any generelizations can be made, but it is interesting to see where these 28 children group themselves.

It can be seen that by far the largest percentage of the general population (column 2) falls in the arerage category and that the percentages of the general population included in other categories become smaller and smaller as one moves away from the average toward the extremes of the distribution. The Louisville and Jefferson County Children's Home commitment group, on the other hand, ralls more largely into the dull normal, borderline, and mental defective ranges than does the general population, with few in the average, bright normat, and superior categories. To quote Miss Elizabeth McCarley, Head of the Paychology Department, Iouisville and Jefferson County Children's Home, "Our reports, in reference to children's levels of intelligence, more orten contain the terms dull normal and borderline than the terms

Florence Teagarden, child Psychology for Professional
Workerg (rev. ed.; New York:


superior and bright normat." ${ }^{1}$ In this connection, then, it can be seen that the 28 chilaren included in this study align themselves within the categories one might expect to be more popular in the Louisville and Jefferson County Children's Home. Table s shows two relationships: (1) the relationship between level of intelligence and educational achievement as portrayed by the results or psychological testing, and (2) the relationship between the child's actual school grade placement and his educational achievement.

The verbat cores or the intelligence test were used as the basis for categorizing the child as avorage, dull normal, etc. His educational achierement was secured r rom the results or an achierement test. In most cases the Educational quotient and the grade score were given, which showed the level at which the child had teated to pertorm in school work. When his performance was on a par with his level or intelifigen, the writer interpreted and tabulated this as standard (column 3 ); when his performance was bolow bis native ability, he was considered as below (eolumn 4); when no achievement test was adminlstered, the writer used the unknown eolumn (5).

It was felt that it was more rair to make a comparison between the child's grade placement and his achievement than between his placement and his level of intelifgenee, but all

Memorandum ritten by wizabeth MeCarley, Psychology Department, L\&JCCH, "Classirieation or Intelligence According to Test Performances," December 12, 1947. 
TABLE 3

RELATIONSHIP OP EDUCATIONAL ACHIEVEMENT BY LEVEL OF INTELLIGENCE AND GRADE PLACIMENT BY LRVEL OF INTELIIGENCI AND EDUCATIONAL ACHIEVEMENT

\begin{tabular}{|c|c|c|c|c|c|c|c|c|c|c|}
\hline \multirow{3}{*}{$\begin{array}{l}\text { Level of } \\
\text { Intel11gence } \\
(1)\end{array}$} & \multicolumn{10}{|c|}{ denierement and placement } \\
\hline & \multirow[b]{2}{*}{$\begin{array}{c}\text { Total } \\
(2) \\
\end{array}$} & \multicolumn{3}{|c|}{$\begin{array}{l}\text { Educational } \\
\text { Achierement }\end{array}$} & \multicolumn{6}{|c|}{$\begin{array}{c}\text { Grade Placoment by } \\
\text { sducational Achierement }\end{array}$} \\
\hline & & $\begin{array}{c}\text { Standard } \\
(3)\end{array}$ & $\begin{array}{c}\text { Be } 10 \mathrm{w} \\
(4)\end{array}$ & $\begin{array}{l}\text { Un- } \\
\text { known } \\
(5)\end{array}$ & $\begin{array}{c}\text { Standard } \\
(6)\end{array}$ & $\begin{array}{c}B \circ 10 \pi \\
(7)\end{array}$ & $\begin{array}{c}\text { Above } \\
(8)\end{array}$ & $\begin{array}{c}\text { Special } \\
(9)\end{array}$ & $\begin{array}{r}\text { Un - } \\
\text { known } \\
(10)\end{array}$ & $\begin{array}{c}\text { Non- } \\
\text { attendance } \\
(11) \\
\end{array}$ \\
\hline $\begin{array}{l}\text { Very } \\
\text { Superior }\end{array}$ & - & - & - & - & - & - & - & - & - & - \\
\hline superior & 1 & - & - & 1 & - & - & - & - & 1 & - \\
\hline $\begin{array}{l}\text { Bright } \\
\text { Normal }\end{array}$ & - & - & - & - & - & - & - & - & - & - \\
\hline Average & 10 & 3 & 6 & 1 & 3 & 1 & 4 & - & 1 & 1 \\
\hline $\begin{array}{l}\text { Dull } \\
\text { Normal }\end{array}$ & 9 & 1 & 6 & 2 & 1 & - & 3 & 3 & 1 & 1 \\
\hline Borderline & 6 & 2 & - & 4 & - & - & 1 & 1 & 2 & 2 \\
\hline $\begin{array}{l}\text { Mental } \\
\text { Defective }\end{array}$ & 2 & 1 & - & 1 & - & - & 1 & 1 & - & - \\
\hline Total & 28 & 7 & 12 & 9 & 4 & 1 & 9 & 5 & 5 & 4 \\
\hline
\end{tabular}


the time taking into account his level of intelligence. Therefore, the second part of the table, columns 6 through 11, is interpreted in this way. For example, when a child of average ability (level of intelligence) made a grade score or educational achievement compatible with this level and was also actually placed in a grade at the same level, he was considered standard, column 6 ; if he had been placed in grade below his achievement, he would hare been considered below, column 7. Some children were placed in a special and ungraded classes and this accounts for column 9. Naturaily, it a child had not boen given an achievement test, his grade placement, no matter what the grade, high or low, could not be compared with an unknown achievement. The other columns are self-explanatory.

Wth this interpretation in mind, the table reveals some interesting facts. It appears that nearly one-half (12) of the children upon commitment to the Home did not achieve at their level of intelligence. These were children not at the lowest extreme, for they were average and dull normal. seren of the 28 children showed achievement comparable with their native level; the remaining $g$ either were not given achievement tests or the results of the test were not avallable.

As to actual grade placement, 4 of the children were placed in a grade compatible with their level of achievement; 
3 of these were of average, 1 of dull normal ability. one child, of average ability, was placed below his performance as shown in achievement test. The largest number of children, 9, were placed in a higher grade than shown on the achievement test; 4 of these were of average ability, 3 of dull normal, and 1 each in the next two lower categories. Phese 9 chilaren, it would seem, might encounter some difficulty by the higher placement. It is noted that 5 children were placed in special classes, where the needs of the individual child were considered. This method was often used at the institution, as well as in some of the city public schools. Adjusting the curriculum to fit the special needs of the child where he would rind the regular graded clasgwork too competitive and too difficult is a derice used in many school systems today.

There are many reasons why children do not attend school. It was interesting to see some of the most common reasons for missing school among this group of children. Table 4 gires a picture of this. By showing the results in relation to level of intelligence, the figures are more maningful.

Examination of Table 4 show the signiricant fact that unauthorized absences and lock-up or detention in the Children's center were the main reasons for non-attendance 
TABLE 4

REASONS FOR SCHOOL NON-ATTENDANCE ANY TIME

BY LEVEL OF INTELIIGENCE

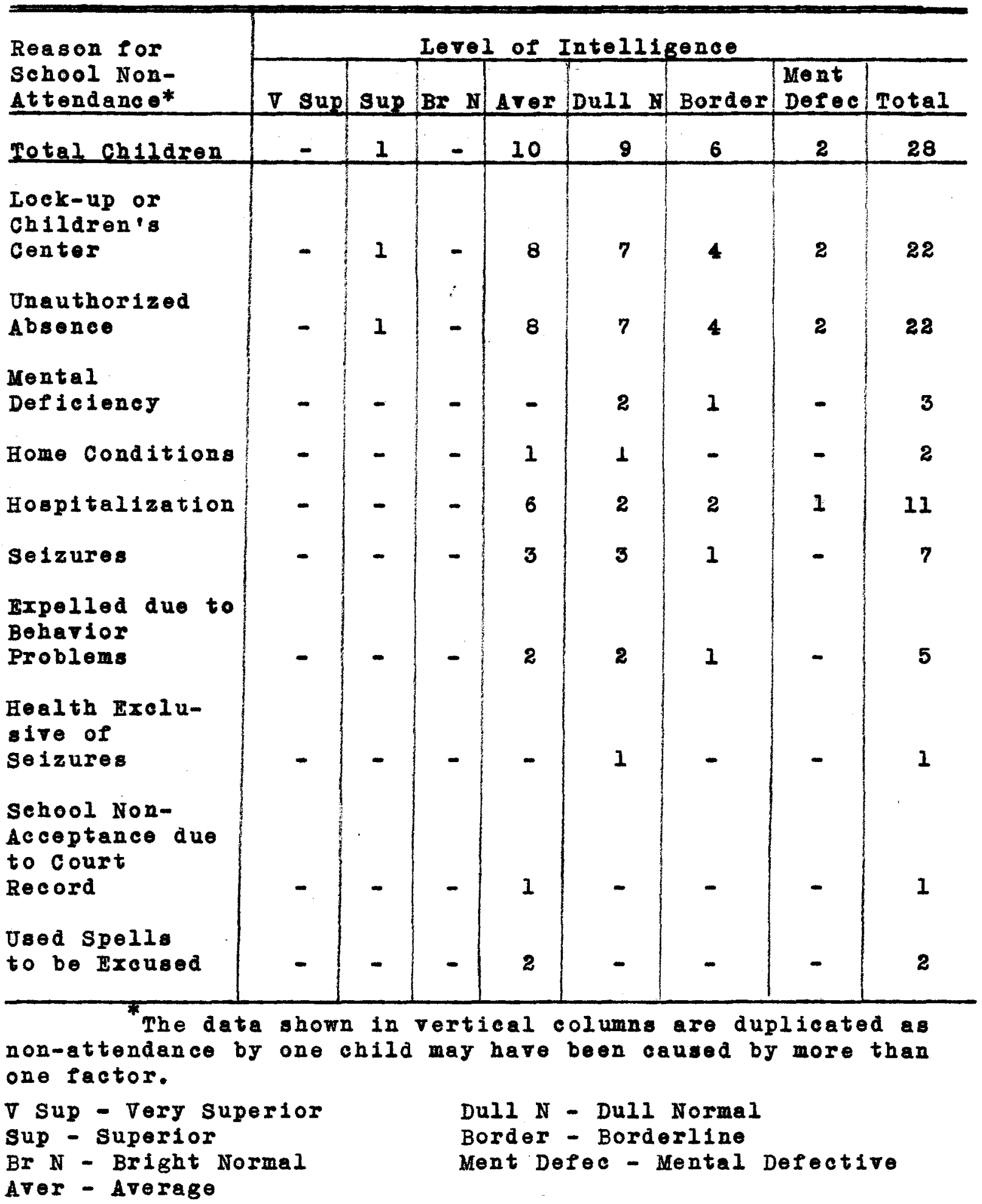


at school by these 28 children. Twenty-two of the 28

children missed school due to these two reasons. The dis-

tribution was falriy even among each lovel of intelligence.

There were 3 children who missed school due to mental

deficiency. Two of these were dull normal and 1 was border-

1ino. The case of Jasper is used as an illustration.

Jasper, ago ll, dull normal, was a thin, sallow facod boy who wa often described as an unhappy and "pathetic" child. He had been in the second grade before commitment. Plans had been made to place him in a foater home with two younger siblings, but due. to his history he was brought to Ormsby Village for study from nourologieal, paychiatric, and psychological angles. He remained on campus for eight months where he felt "picked on" by the other children. His small physique and social inferiority made it difficult for him to defond himselt in the group. As a result of his inadequacies and irritating manner he was constantly picked on."

His teachers at the Village felt he needed to be where he could foel more secure and receive much personal attention. They did not believe institutional life was best for this child. Jasper also was an enuresis problem and an excessive smoker, the latter since the age of four. He had epileptic seizures and was on medication. Some of his behavior was "queer" and "crazy acting," as if he had no reasoning power. All his family considered him feebleminded. He cried incessantly, and his teachers thought he had gone "down hill" and needed the individual attention a foster home could provide. He lacked motor control enough to write and wes unable to do second grade work.

His first foster home placement, after elght months at Ormsby Village, lasted one and one-half months. Jasper went to it "thrilled" over the prospect and with the offer to give up smoking. After a week the foster mother discontinued his medication without consulting the agene $y$, for she thought it made him too "dopey."

Jasper was placed in second grade at the public school. The school was given a psychological report and a history of his problems and needs. His childish mannerisms, nervousness, stealing, and inability to learn made his school supervision very difficult. The school principal 
and teacher retused to allow nim in school and threatened to send nim to Feeble Minded Institute. His foster mother stood by him until the stealing episode, with which she felt unable to copo. She thought him sweet and obodient in the home, though slow and exasperating. She said he was a elever, adaptable child.

Two children did not attend school due to home conditions. These both ocourred during placements in their own homes. Charles is cited as an example.

Charles, a boy of average ability, was committed at 14 a a dependent, in that there was no proper guardianship, no visible mean of subsistence and the home was unf1t. The father had deserted and five younger siblings were all placed in Catholic orphanages.

Charles "marked time" at Ormsby Village. At first ho blamed his mother for his commitment and never wanted to see her. Soon he began a series of unauthorized absences during which he always went home, his mother reporting him shortiy therearter. After a stay of two montho in children's center during which he received poychiatric service pending plans, he was placed at homo with his mother and enrolled in parochial school. This was recognized as a poor situation due to tho mother's rojection of charles and hi consequent resentment of her drinking and immorality. Aftor a stormy two wooks Charles wa willingly returned to the Children's center. His attendance at sehool had been erratic. School authorities and neighbors stated that Charles behared well and thought the mother was the basis of the trouble in their constant quarreling and fighting.

Eleven of the 28 children miseed school due to hospitalization other than that pertaining to their seizures. seren children did not attend school because of their seizures. Three of these were of average ability, 3 were dull normal, and I was borderline. Douglas, the boy' of borderline ability is used as illustration. 
Douglas began to have grand mal seizures at the age of 11, two years after his commitment and while he was at Ormsby Village. : Immediately following commitment he was placed in his irst and only foster home where he remained for ten months. He made a atiafactory adjustment, was sociable and made Iriends quickly. He was returned to ormsby Village because the foster mother secured full time employment.

Douglas then stayed at Ormsby Village for rour years. It was during this time that his epileptic seizures began. He was a small boy and used that as an excuse to get out of work. He was very babitied, cried rrequently and capitalized on his size. His conduct was tair, with occasional temper tantrums. As his attacks diminished he became more nervous. His cottage mother described him as "absolutely truthful, never impudent, and the best child on campus." He was rinally placed at home with his elderly grandmother and half-sister who was teeble minded. The mother, an epileptic, was dead, and the father had deserted. Douglas had been in an ungraded class at the Village, and he was given a similar placement in the city school, where he adjusted well and was happy. He remained in school in such an assignment for two years. The teachers and children were fond or him.

Then he began having seizures again. He was so embarrassed when they happened at school that he was allowed to withdraw trom sehool. The school telt he had made no progress whatever in his worx. He was 16 years old at the time. At the death or the grandmother, there were no relatives wlliing or rinancially able to take responsibility ror Douglas.

During his placement with his grandmother it was felt that he had deteriorated mentally. He was socially inadequate, wandering about on his bicyele until very late at night. He could not keep himselr clean or properly clothed. He was in no way equipped to support himself. In his own words he could do nothing but "ride a bike." Douglas had, nowever, shown some aptitude with his hands. In view or all this, he was tiled on tor admission to Kentucky Training school (formerly Feoble vinded Institute). To substantiate this a later psychological test was given. In this he tested at the lowest point in the borderline group. one point lower on the test would have placed him at the high moron level. Douglas was accepted by and entered Kentucky Training school. 
There were 5 children who were expelled because of behavior problems. It is interesting to note that 2 were of average and 2 of dull normal ability.

one boy was placed in a private, religious boarding school by his mother soon after his commitment to the ageney. He had average ability and offered no problems except for the complaint that he would not atudy. His stay there was shortIived. When the school learned he had a Juvenile court record they refused to keep him.

Two children, of average ability, nusedn thoir spolls to get excused from school. one boy did not want to take Physical Education while placed at home. He arranged for an excuse from a private physician even though the agency physician would not recommend his exemption from the class.

\section{Reeson for Commitment}

The statutes of the Louisilile and Jefferson County Children's Home provide for the care of dependent, neglected, and delinquent children. Howerer, the Jefferson County Juvenile Court commits children on only either of two bases, dependency or delinquency. It has been stated that by far the largest number of the children committed to the ageney 1 were neglected. Table 5 shows the reason for commitment according to sex and race.

1
May, 1948.

Personal interview with Mrs. Catherine Y. Fox, 
TABIE 5

REASON FOR COMMITMENT BY SEX AND RACE

\begin{tabular}{|c|c|c|c|c|c|c|c|}
\hline \multirow{2}{*}{$\begin{array}{l}\text { Reason for } \\
\text { Commitment }\end{array}$} & \multicolumn{3}{|c|}{ Male } & \multicolumn{3}{|c|}{ Female } & \multirow[b]{2}{*}{ Total } \\
\hline & White & Negro & Total & White & Negro & Total & \\
\hline Dependency & $10^{b}$ & $3^{a}$ & 13 & 3 & 1 & 4 & 17 \\
\hline Delinquency & $8^{8}$ & 2 & 10 & 1 & - & 1 & 11 \\
\hline Total & 18 & 5 & 23 & 4 & 1 & 5 & 28 \\
\hline
\end{tabular}

quent.

ane child was committed a second time as a delinent.

bone child was committed a second time as a depend-

cone child was committed a second and third time a a delinquent.

The majority or the children were committed on

dependency rather than delinquency charges. This would serm to bear out the abore statement that many children were neglected. Some children brought in to court on delinquent charges in the petition are frequently committed as dependents. This might seem to be due to the fact thet upon court investigation the child was seen to be more neglected than delinquent, thus causing the court to change the charges from delinquency to dependency. The writer has no facts to substantiate this observation. Of the 23 boys in the group, the basis ror commitment was rairly evenly divided--13 on dependency and 10 on aelinquency. The girls showed a less balanced picture. Five girls were committed; or these, 4 were for dependency and 1 tor delinquency. 
The fact that 4 children had recommitments is not as significant as one might first believe. one boy had three commitments, each upon the basis or delinquency. This was really a matter of technicality by the Juvenile court for there was no break petween the dates of release and recommitment. During the time of this boy's commitment, the Jurenile Court judge instituted the practice of the agency releasing any ward of the Louisville and Jefferson County Children's Home who was to apear in court on charges. Therefore, this boy was released by the agency, only to be recommitted to the agency immediately thereater.

With the other 3 children, there was a lapse of time between release by the agency and recommitment by the Juvenile court. The oase of stephen, who had two commitments for deIinquency is cited. He ran away when returning rrom Louisville General Hospital to the Chilaren's Center atter receiving an electroencephalogram. This was three weoks after his commitment. Stephen was not apprehended, and the case was carried by the agency seren months betore he was released. It was beliered but unconfirmed that he had been stajing with relatives from time to time during this period. Reasons given for his release were: the agency's belief that he would be a serious school problem and behavior problem at ormsby Village because he was so easily led; the agency doubted his mental 
ability (borderline range) to control his delinquencies. He was recommitted elght months later on the charge of thert of a motor scooter. At the same time stephen's mother was fined ror contributing to nis delinquency. stephen was given a suspended sentence to Kentucky Houses of Reform on his recommitment. From the time he was placed at the Village he was either absent without leave or in the lock-up. His last unauthorized absence was two months long, when he was picked up on charges of stealing and wrecking a truck, carrying burglary tools, and eutting a sereen door at an A\&P store. His suspended sentence to Kentucky Houses or Reform went into effect and he ras committed to that institution. There was very litte opportunity ror any service to de orfered by the agency to this boy.

\section{Broken Homes}

The stability of the nome has a great effect upon children and their beharior and happiness. Many children who are well physically Iind the emotional stress and strain or home conditions sometimes hard to bear. Children who have the further handicap or seizures have an additional disadvantago. It cannot be accurately measured how great a part this might play in the chlld's ability to accopt his condition and adust socially, but it is interesting to see how many children in the group came trom broken homes. Table 6 is presented to show this in relation to the basis for commitment. 
TABLE 6

CEILDREN FROM BROKEN HOMES

BY BASIS OF COMMITMENT

\begin{tabular}{l|c|c|c}
\hline \hline Reason for & \multicolumn{3}{|c|}{ Status of Home } \\
\cline { 2 - 4 } Commitment & Broken & Not Broken & Total \\
\hline Dependency & 16 & 1 & 17 \\
Delinguency & 6 & 5 & 11 \\
\hline Total & 22 & 6 & 28 \\
\hline
\end{tabular}

More than three-fourths, or 22 or the children came

from broken homes. As to reason for commitment, 16 of the 22 from broken homes were committed for dependency and 6 for delinquency. of the 6 who came from more stable homes, I was committed for dependency and 5 for delinquency.

Admissions to Children's center

Since the Children's Center is used by the Louisville and Jefferson County Children's Home both before and after the children are committed to the agency as wards, it is interesting to see how many admissions each child had. Table 7 presents the findings on each of the 28 chilaren.

The number of admissions for each child is shown before and after commitment. There is a Iurther break-down as to dependency or delinquency. After a child has been commited to the Louisville and Jefferson County Children's Home either as a dependent or a delinquent, his subsequent admissions at the 


\section{TABLE 7}

ADMISSIONS TO CHILDREN'S CENTER BEFORE AND ATTER COMMITMENT TO LOUISVILLE AND JEFFERSON COUNTY CHILDREN'S HOME

\begin{tabular}{|c|c|c|c|c|c|c|c|}
\hline \multirow{3}{*}{$\begin{array}{l}\text { Case } \\
\text { Number }\end{array}$} & \multicolumn{4}{|c|}{ Admissions to } & \multicolumn{3}{|c|}{ center } \\
\hline & \multicolumn{3}{|c|}{$\begin{array}{r}\text { Before Commitment } \\
\text { to L\&JCCH } \\
\end{array}$} & \multicolumn{3}{|c|}{$\begin{aligned} & \text { After } \text { Commitment } \\
& \text { to } \text { I\&JCCH } \\
&\end{aligned}$} & \multirow{2}{*}{$\begin{array}{l}\text { Total Number } \\
\text { Admissions }\end{array}$} \\
\hline & $D \in p$ & Del & Total & Dep & Del & Total & \\
\hline 1 & - & 3 & 3 & - & - & - & 3 \\
\hline 2 & - & 9 & 9 & - & 7 & 7 & 16 \\
\hline 3 & 1 & $I$ & 2 & 1 & - & 1 & 3 \\
\hline 4 & 1 & - & $\perp$ & 5 & - & 5 & 6 \\
\hline 5 & 1 & - & 1 & 4 & 1 & 5 & 6 \\
\hline 6 & - & 5 & 5 & - & 1 & 1 & 6 \\
\hline 7 & - & 4 & 4 & - & 2 & 2 & 6 \\
\hline 8 & 1 & - & $I$ & - & - & - & 1 \\
\hline 9 & - & 5 & 5 & - & 3 & 3 & 8 \\
\hline 10 & 1 & - & 1 & - & 5 & 5 & 6 \\
\hline 11 & - & 3 & 3 & - & 7 & $?$ & 10 \\
\hline 12 & - & 6 & 6 & - & 6 & 6 & 12 \\
\hline 13 & 4 & - & 4 & 1 & 2 & 3 & 7 \\
\hline 14 & - & - & - & - & - & - & - \\
\hline 15 & 1 & - & 1 & 2 & - & 2 & 3 \\
\hline 16 & 2 & - & 2 & 2 & 1 & 3 & 5 \\
\hline 17 & - & 7 & 7 & - & 5 & 5 & 12 \\
\hline 18 & 1 & 2 & 3 & - & 5 & 5 & 8 \\
\hline 19 & 4 & - & 4 & - & $\perp$ & 1 & 5 \\
\hline 20 & 1 & - & 1 & - & - & - & 1 \\
\hline 21 & 1 & - & 1 & 6 & 6 & 12 & 13 \\
\hline 22 & 1 & $\perp$ & 2 & 2 & 4 & 6 & 8 \\
\hline 23 & 2 & - & 2 & $y$ & 9 & 18 & 20 \\
\hline 24 & - & 4 & 4 & - & - & - & 4 \\
\hline 25 & - & $\perp$ & 1 & - & - & - & 1 \\
\hline 26 & 1 & 3 & 4 & - & 9 & 9 & 13 \\
\hline 27 & - & 4 & 4 & - & 1 & 1 & 5 \\
\hline 28 & 1 & 2 & 3 & 3 & 7 & 10 & 13 \\
\hline Total & 24 & 60 & 84 & 35 & 82 & 117 & 201 \\
\hline
\end{tabular}

L\&JCCH - Louisville and Jefferson County Children's Home Dep - Dependency Del - Delinquency 
center carry the same designation, unless charges of the other designation have been Illed against him. If the court changes his status from a dependent to a delinquent, or vica versa, his subsequent admissions then carry the new designation. This means, then, that a ward of the Louisville and Jerferson County Children's Home, committed as a dependent, would thereatter be admitted as a dependent at the center from any number or unauthorized absences unless delinquent charges were Iiled aggingt him uy someone. By the same reasoning, it a child was committed to the agency as a delinquent and thereatter shoved a great number or delinquent admissions to the center, it would not necessarily mean that he was entered each time because he had done something or behaved in a delinquent manner, although it might mean that. He might be admitted for any of the reasons as previously stated, such as special treatment or study.

Table 7 shows that 1 chila, Case Number 14 , was never known to we Children's Center. This was an unusual case, for seldom is a chila committed to the agency without irst going through the process of admission to the center and all that goes with it. In the case of Ann, howerer, circumstances altered the usual procedure.

Ann, the illegitimate child of a feeble-minded mother, had been under the supervision of a private children's agency since the age of three, placed rirst with the mother and a year later in a toster home. She was committed to the Louisvilie and Jefferson County Children's Home two years later at the request of the children's agency when she

I Supra, p. 14. 
was six. Since Ann had made such an excellent adjustmont in the roster home, the children's agency oftered to turn the home over to the Louisville and Jefferson County Children's Home as a foster home in order that Ann might remain in a home where she seemed happy and secure. These arrangements were made, which account for Ann's total lack of admissions to the children's center

As to the other cnilaren, it can be seen that all were known to the Children's Center before commitment. Although Table 7 does not reveal this, the writer observed in the study of the cases that a great many of the center admissions rollowing comitment were due to unauthorized absences.

No generalizations may be derived from this table as to the adjustment of the children. It is merely a portrayal of the number of times the child was known to the center. 'It indicates, however, the variation between children and the fact that there must be underlying causes. The case of Russell, Case Number 23, who had a total of 20 admissions to the center, is used as an illustration. When compared with Table $12^{1}$, infra, this table has greater signiticance.

Russell, of dull normal ability, was committed as a dependent at the age of six with two older siblings. The mother was ill; the tather worked and was unable to supervise. Three other older siblings had been previously committed. There were two younger siblings in the home. All were of borderline or dull normal intelligence.

Russell was considered the least attractive member of his family. He was frail and undernourished, and his left arm and shoulder were severely crippled as a result of infantile paralysis when six months old. His history bears 
out rejection, neglect, and disinterest on the part or his family, especially the mother. The father died when Russell was ten. Russell was described as sullen, lazy, extremely dishonest, destructive, sneaking, vulger and unclean in habits, and a severe behavior problem due to frequent unathorized absencesand stealing episodes.

This boy was a ward of the agency until the age of twelve. Within a two year period he had five foster home placements and one short placement at home. His second home placement at the age ot eight lasted approximately one year, when he was returned to the Village for a period of three years until bis final placement at home and the subsequent release within a month. Due to undernourishment and his erail condition Russell remeined out of school the first year while in a foster home. There were other wards in the home but none of his siblings. Here ho was the baby of the family and received a good deal of attention. He improved greatly in health and attitude but was still ditricult to hande and inclined to be babyish. The foster mother requested his remoral because he was not trustworthy and because of some stealing.

Russell was placed at home because his mother's health had improved. This placement lasted three months. He requested a foster home. About his own home he said: "I aln't got nothing." There were domestic difficulties, the mother became ill again, and Russell and an older sister were placed in another roster home. This foster mother found the children hard to manage and they were removed within three months.

The home situation was very bad during the one year period Russell wa placed there. There were frequent absences and stealing. The standards were very low and none of the children was given any training or discipline. They were picked up by the police many times.

It was after his return to the Village that Russell was found to have an abnormal electroencephelogram and he was placed on medication. There was little or no improvement, however. He was seen by the psychiatrist and psychologist at various times. It was relt that he failed to respond to any kind of treatment. The cottage mother described him as a "dried up little old man," and he made a patnetic picture. He was confused and expressionless and showed very little responsiveness. 


\begin{abstract}
After the rather's death and when the mother was receiving pension money ror the three younger children, she was not interested in Russell and the next two older children. She especially dia not want Russell. He never heard trom his mother or ramily when he was at the Village.
\end{abstract}

The above case illustrates a child whose many admissions to the center were for the most part due to poor adjustment in various placements and to repeated and erequent unathorized absences. Russell's status changed from a dependent to a delinquent atter his arrest at home tollowing an absence at the time of his rather's funeral when he was involved in a stealing episode.

\title{
Siblings
}

There is no table to present the findings as to the siblings of the 28 children included in this study. Generally speaking, however, these children came trom families with several children, for there were only 2 who had no siblings. One child's parents and Iamily history were unknown. The remaining 25 children had siblings ranging in number from 1 to 8. Seven children had 2 siblings, 5 children had 3 siblings, 4 children had 5 siblings, and 4 had 6 siblings. only, 1 child had 8 siblings. The cases revealed both the characteristics of warm, close relationship between chilaren as well as sibling rivalry.

History or Seizures in the Family

As far as is known, 8 of the 28 children had a history of seizures in some member of the family. Five of these 8 
children had seizures also; the other 's showed a predisposition to epilepsy and were considered behavior problems.

\section{Classification of Medical Diagnoses}

The diagnoses of the children were varied and did not fall readily into the three types of epilepsy as have been aescrioed previously. Instead, the records often contained the term "idiopathic," which is synonymous with "true" or "essential" epilepsy. Lennox believes "essential" (or "idiopathic") is synonymous with "hereditary"; "symptomatic" epilepsy, on the other hand, is "acquired." Although meny doctors believe the two groups are aistinct, he feels that in most patients both hereditary (essential) and acquired 2 (symptomatic) causes combine.

The classitication used by the writer in Table 8 seemed to be the most natural grouping according to medical diagnoses, since all children were not definitely diagnosed to have epilepay. It was found that the children fell into four groups: (1) those with a dignosis of epilepsy of whom some carried more than one diagnosia; (2) those diagnosed as borderline epilepey; (3) those diagnosed as predisposition to epilepsy; and (4) those who had possible epileptle seizures which were never derinitely diagnosed as epilepsy.

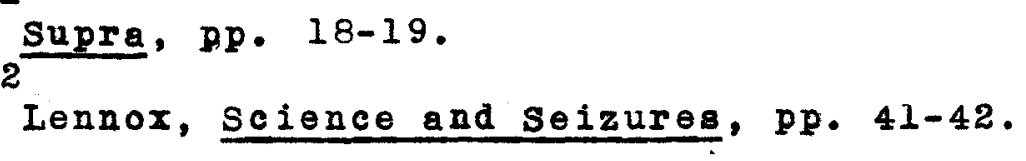


TABLE 8

CLASSIFICATION BY DIAGNOSIS OF CHILDREN WITH SEIZURES AND PREDISPOSITION TO EPILEPSY

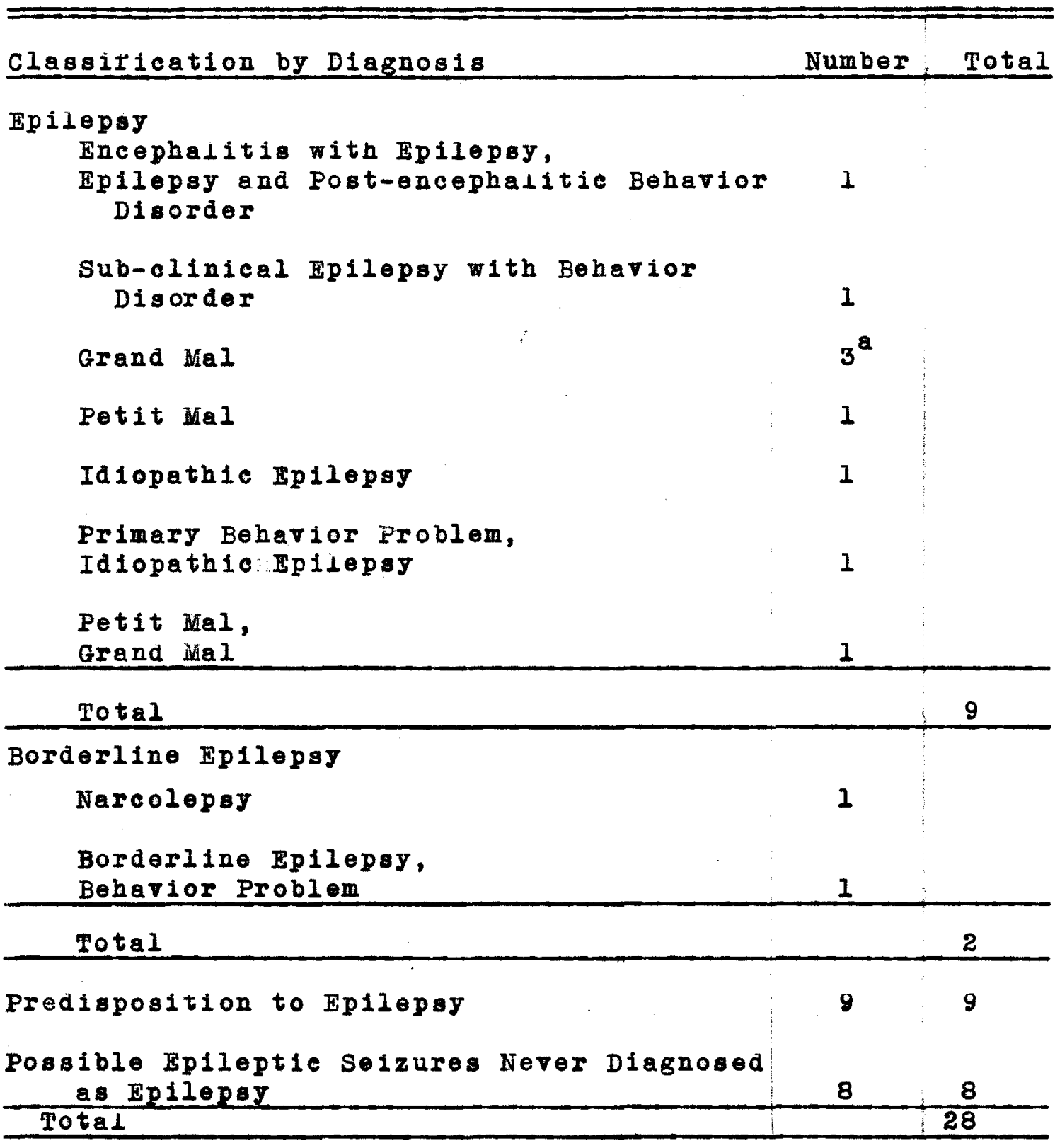

aone child was released from the agency with a diagnosis or epilepsy with psychosis. 
There were 9 children in the first group; 3 of them carried behavior disorder or problem as a part of the diagnosis of epilepsy or as an aditional dignosis. Threo children had grand mal epilepsy, and 1 had grand mal in combination with petit mal. One child with grand mal was diagnosed upon release to have epllepsy with psychosis.

There were 2 children with borderline epilepsy. one had narcolepsy, which is characterized by attacks of sleeping. The second child was diagnosed to have borderline epilepsy and behavior problem.

Nine children were included in the third group, predisposition to epilepsy. These children all showed abnormal electroencephalograms. Without exception, they all made a poor social adustment and had many problems during their period of commitment.

The fourth group included 8 children who had experienced seizures, some of which were at first thought to be epileptic but were never given a definite diagnosis of epilepsy. The case of Halcolm is an illustration.

Malcolm, of average intelifgence, was a ward of the agency for two years and was committed at the age of 13 as a delinquent for purse snatehing. He had been in court on three previous rilings involving stealing. He was the oldest of five children. There were two older half sisters in the home, children of the father's first marriage. Halcolm was his mother's tavorite. He was jealous of his little sisters; he was never impudent to his mother. The father was a hard working shoo repair man, devoted to his ramily, who turned over all his income to the wife. She managed everything--the home, budget, children, etc. She was intelligent and a hard worker. 
Following commitment Malcolm broke out of the children's center and was absent for over a month. He was returned when apprehended for destroying property. The mother worked out an approved plan to send Malcolm to a boarding school. He remained only two weeks and did not adjust too well. When his court record was learned, the school refused to keep him. He was again admitted to the center when brought in on charges. He was placed at ormsby Village where he remained for seven months.

His adjustment was good the first two months. He received psychiatric treatment, and progress seemed to be made. However, when plans for placement at home tell through due to the rather's illness, Nalcolm went completely to pieces. He was persistently absent tor long periods of time. At his parents' request he was placed in a toster home, and arrangements were made to continue his psychiatric treatment on Saturdays at the center. Malcolm failed to return to the foster home from most or these conferences, going instead to his own home and stating that he had been given permission not to return to the roster home. It was while he was in the foster home that the question of his having petit mal epilepsy came up, aue to his sudden periods of "flattening" and restlessness. The matter of his stealing as an epileptic equivalent was also discussed in conterence. His teacher round him able to do his work but his mind was "somewhere else." The electroencephalogram showed marked abnormality.

Two months atter his foster home placement he was returned to the center and from there placed at ormsby Village, where he was to receive medication and treatment. He did not adjust at the cottage, was very belligerent, and took delight in upsetting people. He had nightly furor attacks which disturbed him and the group. He was considered obscene and even dangerous, when he threatened to kill another boy. He was thought emotionally incapable of understanding the consequences of his acts. Fe was placed on the Psychiatric Ward at Louisville General Hospital for one month for study and observation. Another electroencephalogram, after medication had been given, continued to show abnormality. change in medication was recommended.

It was after this period of observation that the social Service Department requested a derinite diagnosis from the psychiatrist on Malcolm and tour other children. The report follows: "I see no evidence for placing a label on them of a definite sort. . . . there is behavior abrogation and.. - there has been demonstrated some functional 
disturbance, but to place this label on them[epilepsy]I feel would be a detriment to their long time treatment. I am very anxious to avoid any implications that this is true epilepsy."l

Upon his return to ormsby Village, psychiatric treatment was continued as well as medication, and he was given a Work asgignment with special arrangements made tor private tutoring in school work. There was some improvement, but he was disturbed because he could not quit school and go to work. His attitude was that since he had not been able to trust his tamily--plens for placement never materializing--he could not trust anyone. In any relationship he thought in terms of being "double crossed."

Malcolm was rinally placed at nome five months before his release. He was to continue to see the psychiatrist, and his mother gave consent for his taking medication, which she had not approved or earlier. He did well at home the first three months, and then he began staying out late and running with a gang of boys. He made threats to "kill all cops"; this embitterment toward police resulted from his blaming them for his tirst commitment. The mother sought the agency's help, admitting Malcolm's need for medication and offering to cooperate in seeing that he got it.

When he was apprehended by the police in a stolen car with loaded pistols he was sent to jall, where he admitted his difficulty. He was released to the Juvenile court for disposition. Further psychiatric study was given over a period of three months. Although he was committed to Kentucky Houses of Reform, the psychiatrist believed there was definite progress made. Melcolm's attitude had changed. He seemed more able to face the results of his acts. There was some growth toward maturity, but whether or not he would use his more mature reelings in antisocial behavior or acceptable social growth was questioned.

The foregoing case history clearly illustrates the

attitude of the psychiatrist toward the stigma of epilepsy. In other cases, there was evidence, also, or seeming reluctance of members or the medical profession to give a specific diagnosis

statement by psychiatrist, Irom a case record, Louisville and Jefferson County Children's Home. 
51

of epilepsy.. One child in the group who had seizures with no diagnosis of epilepsy was described as having "furor" attacks or epileptic equivalent, but the psychiatrist did not consider this epilepsy. Two children were treated as it tor epilepsy and were reterred to in the case record as having epilepsy, but there was no confirmation or this as a diagnosis. One boy had one grand mal-like convulsion; after receiring medication there was no known recurrence, and no definite diagnosis was given. Two children were considered beharior problems, although one had grand mal-like convulsions and the other had seizures resulting rrom brain damage from lead encephatitis. The last child in this group who had seizures was diagnosed as a beherior problem. Although his electroencephalogram was not too irregular, the interpretation or it stated that convulsive predisposition could not be ruled out.

\section{Onset of Seizures and Behavior Problems}

Yahraes states that 70 per cent of patients display their Iirst symptoms berore the age or 20 . The peak age for the development of seizures is during the rirst two years of life, presumably because heredity and prenatal and birth injuries most likely show then. Another high point is during 1 adolescence.

Yahraes, op. cit., pp. 12-13. 
Table 9 show the relationship of the age of onset of seizures and behavior problems with the ege or commitment. It can be seen that 16 of the 28 children were comitted during the adolescent years from twelve on. Incidence of onset of seizures and behavior problems did not occur more frequently during the adolescent years, for only 8 children fell into this period. Four children had seizuros within the first two years of life. of the 28 children, the largest number, 4 , had seizures or behavior problems at the age of eight.

It is interesting to note whother children were committed to the agency before or after the onset of seizures and behavior problems. Since the years shown are in oren years with no months indicated, it was necessary to examine the individual cases where the figures coincided. In all the cases where it appears Irom Table 9 that the commitment age and the age of onset of seizures and behavior problems were the same, scrutiny of the records revealed that the child was committed after the age of onset of seizures and behavior problems. This is significant in that 22 of the 28 children were committed after the age of onset of seizures or behavior problems. In other words, the epileptic condition could easily have been an important and contributing factor in the commitment of the child and in the problems he presented. This was the case with these children. 


\section{TABLE 9}

AGE OF ONSET OF SEIZURES AND BEHAVIOR PROBLEMS BY AGE AT COMMITMENT

\begin{tabular}{|c|c|c|c|c|c|c|c|c|c|c|c|c|}
\hline \multirow{2}{*}{$\begin{array}{l}\text { Age of Onset } \\
\text { of Seizures } \\
\text { and Behavior } \\
\text { Problems } \\
\end{array}$} & \multicolumn{5}{|c|}{ Age } & at & \multicolumn{3}{|c|}{ Commitment } & \multirow[b]{2}{*}{15} & \multirow[b]{2}{*}{16} & \multirow[b]{2}{*}{ TotaI } \\
\hline & & 7 & 8 & 5 & 10 & 1 & 12 & 13 & 14 & & & \\
\hline 1 & & & - & - & - & & 1 & - & - & - & - & 3 \\
\hline 2 & - & - & - & 1 & - & & - & - & - & - & - & 1 \\
\hline 3 & - & - & - & - & - & & - & 1 & - & - & - & 1 \\
\hline 4 & - & - & - & - & - & & - & 1 & - & - & - & 1 \\
\hline 5 & 1 & - & - & . & - & & - & - & - & - & - & 1 \\
\hline 6 & 1 & - & - & . & - & & - & - & - & 1 & - & 2 \\
\hline 7 & - & 1 & - & - & - & & - & - & - & - & - & 1 \\
\hline 8 & 1 & - & - & 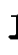 & 1 & & - & - & $\perp$ & - & - & 4 \\
\hline 9 & - & - & - & - & 1 & & - & 1 & - & - & - & 2 \\
\hline 10 & 1 & - & - & - & - & & - & - & - & - & - & 1 \\
\hline 11 & - & - & - & J & - & & - & 2 & - & - & - & 3 \\
\hline 12 & - & - & - & - & - & & - & 1 & - & - & 1 & 2 \\
\hline 13 & - & - & - & - & - & & - & - & - & - & - & - \\
\hline 14 & - & - & - & - & - & & - & 1 & 2 & - & - & 3 \\
\hline 15 & - & - & - & - & - & & - & 1 & 1 & $\perp$ & - & 3 \\
\hline 16 & $=$ & $=$ & - & $=$ & $=$ & & - & $=$ & $=$ & $=$ & $=$ & $=$ \\
\hline Total & 4 & 1 & - & 2 & 2 & & $\perp$ & 8 & 4 & 2 & 1 & 28 \\
\hline
\end{tabular}

Medication and Control by Medication

Although the most commonly used medications ior epilepsy are phenobarbital, dilantin, and tridione, it was found that a great variation or medications was used for these children.

Table 10 show the medications, singly and in combinations, used by the children at any one time. 
TABLE 10

MEDICATION USED BY TWENTY-EIGHT CHILDREN AT ANY ONE TIME

Medication

No. or children

Phenobarbital . . . . . . . . . . 11

Dilantin . . . . . . . . . . . . . . 10

Tridione . . . . . . . . . . . . . . . . . . . . . . 2

Phenobarbital and Dilantin . . . . . . . 11

Phenobarbital and Tridione . . . . . . . 1

Dilantin and Benzedrine.... . . . . . . 2

Tridione and Benzedrine . . . . . . . . . . 1

Phenobarbital, Dilantin, and Ascorbic Acid. . 1

Phenobarbital, Dilantin, and Benzedrine. . . 1

Dilantin, Tridione, Benzedrine, and Sodium

Bicarbinate.......... . . . . 1

Dilantin, Benzedrine, and sodium Bicarbinate. I

Jnknown . . . . . . . . . . . . . . 1

Eleven children used phenobarbital, to used dilantin, and only 2 used tridione. Phenobarbital and dilantin together were used by 11 children. The remaining combinations of medication would seem to show that the medical staff made every effort to place the child on the medication which would benerit him the most. This is seen more clearly in Table ll, which is a numerical listing of the number of different medications each child had.

Although Table 10 does not show this fact, there were 5 children who were taken off medication by doctor's orders at some time during their commitment.

Table 11 shows the number of different medications used by the children. Twenty-four of the 28 children were placed on medication. The remaining 4 never received medication, 
TABLE 11

NUMBER OF DIFFERENT HEDICATIONS USED BY TWENTY-FOUR CHILDREN Number of Different Medications

Number of Children

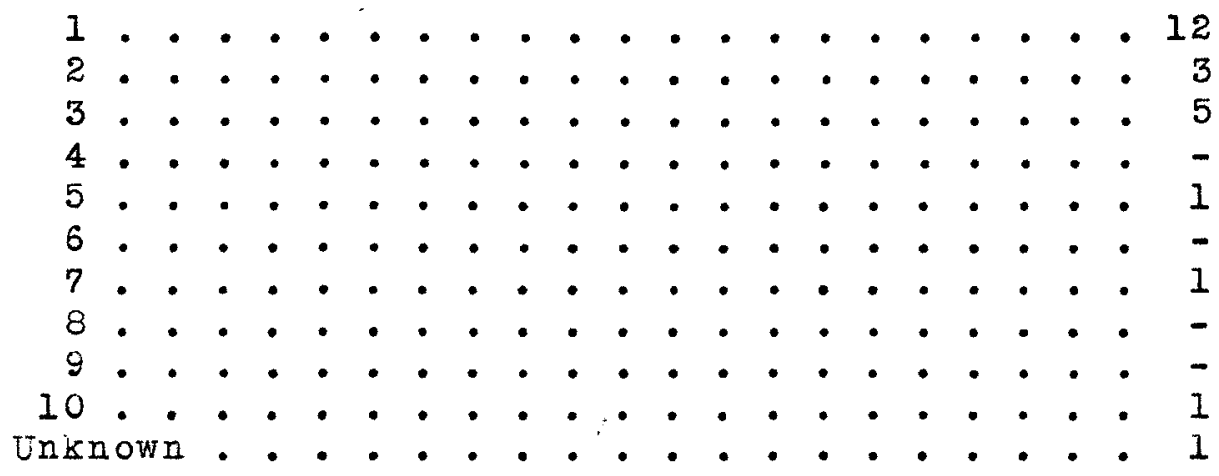

although it was recommended for 1 child as a result of his electroencephalogram. However, the recommendation was not carried out as the doctor believed this boy would not benefit from it.

of the 24 children who did receive medication, 12 used only one medication; 3 children used two different medications; 5 children used three difrerent medications. There were 3 children who had their medications changed many times; I had five different medications; 1 had seven different medications; and 1 had ten difterent medications. In the case of 1 child the medication was unknown. This table signiticantly shows that there was considerable change in the use of medications in drug therapy. It woula seem to indicate that a real attempt was made to control the child's seizures or improve his behavior from the medical angle. 
Was the control by medication effective? As revealed by the case records, the following results were secured for the 24 children placed on medication: good control, 5 cases; fair control, 8 cases; poor control, 6 cases; still experimenting with medication, 2 cases; and unknown, 3 cases. The writer based this classification upon evidence as shown in the records. The diminishing ot seizures and improvement in behavior were considered. Statements made by the physician, the psychiatrist, the cottage mother, the social worker, the teacher, the family--in fact, anyone who came in contact with the child--were noted and interpreted.

only 5 children were considered as well controlled by medication. Eight children showed fair control; 1 of these included a boy whose seizures were controlled fairly well at Ormsby Village and poorly at home. One child whose control was unknown was not placed on medication until approximately one and one-halt years after the medication was recommended. He had not been receiving medication for a period long enough to make an appraisal of the control. 
CHAPTER IV

SOCIAL ADJUSTMENT OF THE GROUP 
SOCIAL ADJUSTMENT OF THE GROUP

The material presented in this chapter does not

lend itself to tabular form as readily as that discussed in chapter III. For the most part, the child's adjustment a shown by his attitudes and feelings, those of his family and others with whom he came in contact in the agency will be discussed.

\section{Adjustment before Commitment to the Louisville and Jefferson County Chilaren's Home}

The problems presented by the 28 children before their commitment to the agency were many and varied. l'hey ranged from a high incidence in such things as stealing, truancy from school, absence from home, enuresis, and inability to get along with other children to a low frequency in other problems. Some of the latter were as tollows: laziness, excessive smoking, complaints by neighbors, pouting, refusing to eat and talk, wanderlust, shooting dice, pulling oft ald clothes, cursing, attacking and detaining little girls, lying, dishonesty, and spitefulness to mother.

The ways in which these problems were handled are revealing. Nine chilaren were known to the Mental Hygiene clinic, and 6 were known to the Louisville General Fospital 
Department oI Fsychiatry. However, the majority of children had appeared in Juvenile court numerous times as a result ot antisocial behavior in the community. The Jurenile court had placed 2 girls in Maryhurst and 1 boy in a catholic orphanage; 1 girl was placed in the temporary custody of the children's Agency. Two cuilaren were placed in private schools by their parents. At least 7 children received corporal punishment from their parents as a means or attempt to curb and control them.

Some of the many other waya parents handled their children's problems were: threaten and command, ridicule, over-protection and no restrictions, wash out mouth with lye, lock in the basement, force to eat, be overly strict, attack with a can opener, bribe with money, and send to the other parent where there was separation of the parents.

Except for seeking help from Louisville General Hospital Department of Psychiatry and the Mental Hygiene Clinic, none of these ways seems very constructive on the part of the parents.

\section{Adjustment in the Institution and during Commitment to the Agency}

The largest number of children met some of their needs by running away. Unauthorized absences were a problem of 24 of the 28 children. The matter of absences will be discussed more fully later and presented in tabular form. 
The following are some of the other frequent problems and attitudes of the children during commitment: aggression, attention getting, witharawal, worry, shame, resentment, feels different, uses spells, enuresis, blames others, impudence, insecurity, lying, stealing, vulgarity, dirty clothes and habits, inferiority feelings, tattling, feels persecuted, feels rejected, sullen, nervousness, meddling, quiet, brooding and moody, disobedience, stubbornness, Iussy and quarrelsome, bully and domineering, profanity, egsily offended, lazy, argumentative, teases and provokes teasing, easily led, does foolish things, carries a "chip," sensitive, tearful, resents authority, homosexual tendencies, masturbation, overt sex behavior, impulsiveness, never satisfied, accepts no responsibility, and many others. Some of the aggression was shown by acts such as temper tantrums, destructiveness, hitting and fighting, as well as by aggressive attitudes.

The ebove shows that the problems of the children were many.

To return to the problem of unauthorized absences, distribution of which is presented in Table 12, it is noted that only 4 children did not run away during their commitment. The remaining children had unauthorized absences ranging in number from 1 to 22 , with one child having an unknown number. The latter had 3 known anauthorized absences from ormsby Village and an innumerable and unknown number from the foster home and his own home. Twenty children had 5 absences or less; 
TABLE 12

DISTRIBUTION OF UNAUTHORIZED ABSENCES BY TWENTY-EIGHT CEILDREN

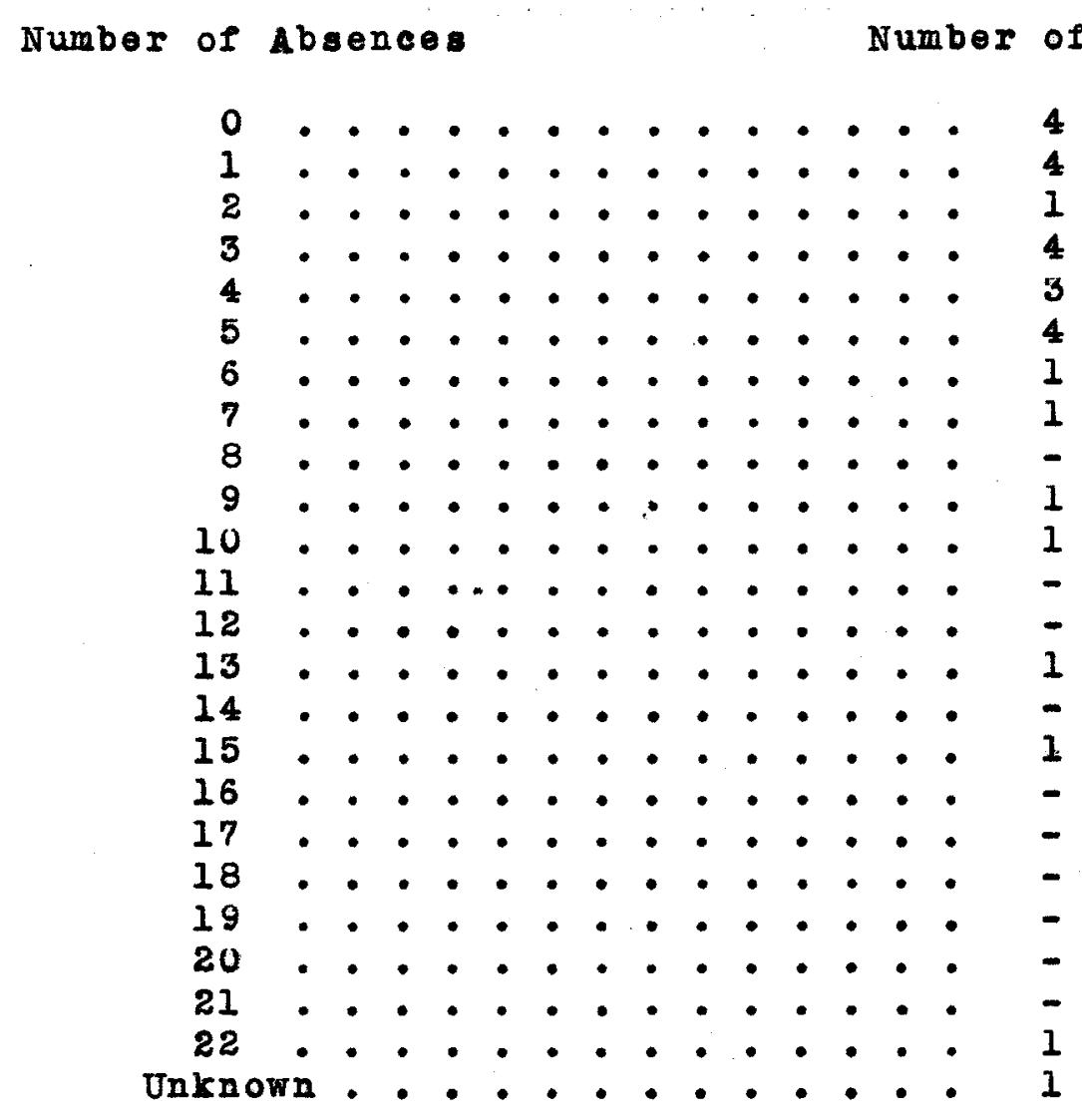

the remaining 8 children each had absences numbering over 6 . The child with 22 unauthorized absences was Russell, who showed the largest number or children's center admissions, as presented in Table 7 .

One of the most interesting cases with reference to unauthorized absences was that of Harold, who ran away 13 times.

1 Supra, p. 41 . 
Harold was the midale of three boys. He lired In a "world of his own" and had made a poor social adjustment; the sibling were outgoing. He wa compitted at the age of 13 and released three years later when he was conmitted to Central state Hospital. He was dignosed to have primary behavior problem and ldiopathie epilepsy. His level of intelligence was low average. His seizures had begun at the age of 11 and prior to commitment he had been having three or four attacks month. The father was hospitalized for cancer of the stomach at the time of Harold's commitment and died shortiy thereafter. Harold was known to Mental Hygiene clinic before his commitment to the agency.

Harold was committed as a delinquent for accosting and detaining little girls. The mother, a very nervous person, was rery defensive and displayed an attitude or complete absorption or him. It was belleved that Harold wa fighting her domination, and his absences were looked upon by the paychiatrist as posible progreas. On three of his absences he was apprehended in West Virginia; on several others he always went in that direction.

Harold was at Ormsby Village for one year before a change in status was made. During this time he had shown much improvement and was beginning to act like a normal boy with girls his age, no longer showing alushed embarrassment. He had had no selzures ror tive months. After his older brother married, Harold lelt he might also be able to break away from home and hig mother's domination.

His placement at home was unsatisfactory and lasted only three months. His seizures began immediately upon his return home, which seemed to indicate the pressure was too great for him. His mother beliered him norer-sexed" and thought an operation might help. When Harold was returned to the center ror detaining a littlo girl, the mother denied the possibility; she pretended ignorance of it when later confronted by witnesses.

Harold then remained at the Village for fourteon months until he was hospitalized for an eye injury. This period at ormsby Village was characterized by more unauthorized absences. There was no improvement in his condition, although he was on medication except during absences. After he was given a summer work asgignment on the farm he improved gradually. He gained weight and had no seizures that were known. The mother visited but was not quite as absorbing due to a sick daughter-in-law and new grandchild who had moved into the home while the older son was aray in service. 
The mother requested Harold's placement at home again but the Board deferred this for two months. Reforences thought it dangerous for him to be in the community due to his repeated offenses with girls.

Arrangement were made for Harold to be placed at home after his hospitalization. This wa not a satisfactory adjustment. His mother was over-protective and anxious. Harold felt she would not let him "grow up." They had frequent clashes. He could not accept the fact that he could not have as much freedom in his activities as his younger brother. He felt he was being punished by limitation of activity, necessary because of bis seizures; this he resented very much. His seizures became more frequent followed often by periods of extreme irritability and violence. On two oceasions in less than two months it was necessary to bring him to the center because in a fit of violence he cut his brother, struck his sister-in-law, and tore the telephone from the wall. He made serious threats as to the use of a gun if he could obtain one.

The mother had a difficult time trying to face reality with regard to what was best for Harold and her responsibility for him in connection with the safety of others. She tried to place the responsibility either with the agency or the doctors. However, she rinaliy made a voluntary filing on Harold for his commitment to central state Hospital. Although the work done by the agency with Harold and his family did not seem to have terminated in success, it was belleved that both he and his mother gained a better understanding or each other and were better able to face the future than before.

It should be pointed out that some children with only 2 or 3 unauthorized absences were gone for periods of 3 to 9 months, while others left and were returned the same day or shortly thereafter. Some children even returned themselves. Some children seemed almost glad when they were found at a place where one might expect them to be; it sometimes appeared as if they wanted to be brought back but could not take the otep alone. From a cereful study of the records it seemed that no two cases were the same. Unauthorized absences were a problem 
with many of the children. In all cases there was a reason for them, although the child was orten unawere of what the emotional need was and how the absence met this need.

$$
\text { Attitudes of the Family }
$$

One of the most signiticant impressions gained from the study was the prominence of rejection by the family, especially by the mother. Rejection was seen in 22 of the 28 cases studied. Many of these children were not rejected due to epilepsy per se; rather, the whole child was rejected. on the other hand, it is hard to draw a Iine and say where or how much is due to the epilepsy which colors the personality ot the child as a whole. Phere were cases where it could be clearly seen that the seizures were the basis tor the rejection.

The fact that the child had seizures caused some parents to over-protect the child. over-protection was seen in the cases of 8 children. In the cases of 9 children the parents exhibited worry. Eight children's families were helpful; the family attitudes of 6 children were shame for his seizures; and 6 families displayed misunderstanding and ignorance of his condition. Six children had no interest at all shown in them as revealed by no visits or contacts from the family. The parents of 3 children were fearful. Three families thought their child different, and 3 were orerindulgent. 
some of the other feelings and attitudes shown by the families were as follows: resentment, dislike, neglect, non-acceptance, defensiveness, blame of one parent by the other for the child's condition, over-criticism, belief that the chila was feeble-minded when he was not, and unwillingness to take responsibility. On the positive side there were a few, but very few, instances of acceptance, interest, concern, and intelligent understanding shown by the families. It can be seen, then, that generally speaking the child as a whole was not accepted, understood, helped with his problems or encouraged in arriving at a socially acceptable and satistactory adjustment to life.

\section{Attitudes shown by others in the Agency}

It was not possible to secure specific figures for this phase in the child's adjustment during his commitment to the agency. However, some general impressions as revealed by the case records are telt to be of importance, since the way people feel torard each other is one indication of their adjustment.

The attitudes of the cottage mother toward the child seemed to indicate a selection by the agency of well-qualified personnel for this very important role. In nearly every case, the cottage mother showed liking, sympathy, interest, patience, and helpfulness toward the child. There were a few isolated 
cases where dislike, disinterest, and impetience were thought to be shown. Some cottage mothers feared the child when violent, but surprisingly enough, many did not react in this way although they felt the child should be removed for the safety of the other children.

The most commonly noted attitudes shown by other children in the institution toward the child were some of the following: dislike, fear, unkindness, teasing, avoidance, non-acceptance, and "think he!s crazy."

For the most part the teachers at the institution showed sympathy, interest, patience, and understanding. It was not possible to secure very much information on the attitudes of teachers who had contact with the child while he was placed off the campus. Some of the outstanding instances, however, were attitudes of misunderstanding, impatience, and non-acceptance, even when interpretation was given by the social worker. There were also positive evidences of patience, understanding, sympathy, and interest.

The social workers showed interest, sympathy, patience, understanding and aceptance for these handicapped children. The writer recalls only one case wherein the social worker repeatediy referred to the child's low mentality in spite of peychological tests to the contrary.

Foster mothers were often very patient with the child and showed kindness, sympathy, interest, and warm affection; 
however, there was often a lack of understanding of the child's condition and his problems. Most or the foster mothers could not cope with stealing, and many did not have the patience to accept behavior problems that were repeatedif evident and which failed to clear up.

It is interesting to see how the child and his problems were handled by the agency and while in the institution. Twenty-four or the 28 children were known to have boen placed in the lockup. Twenty-four chlldren received care with medication to control their seizures and beharior. Fighteen children received pojchiatrio service from the Psychiatric Department of the ageney, while 7 children were rererred to the Louisville General Hospital Department of Paychiatry. Four chilaren vere separated from others in the institution and placed in isolation. Corporal punishment was resorted to in a rew cases; there were quite a fer children who were given reprimands. Howerer, the usual method of discipline and control while at the institution was through the operation of the citizenship aystem--earning a higher rank and enfoying the privileges incident to it when eligibility was established, and receiring reduced citizenship and its accompanying deprivations when that was indicated. ordinarily, the children at ormaby Village have a high regard for their citizenship status. 
With all children, whether at the institution, in a foster nome, or in their own home, case work service from a social worker was given throughout the entire period of commitment. In many cases there was a very good relationship between the child and his worker. This was not always as apparent in the cases in which there was frequent change of workers.

\section{Paychiatric Referralo}

The extent to which psychotherapy was used with the 1 group of chilaren is shown in tabular analysis. This was prepared to show rererrals to such service before and after commitment to the agency. The resources used were the Mental Hygiene CIInie, Louisville General Hospital Department of Poychiatry, and the Louisille and Jefferson County Chileren's Home psychiatrist. Each case is listed with the type or rererral, it any, indicated.

The analysis show that 13 children received psychiatric service from one or more of the three resources before commitment and 20 children received psychiatric service after commitment. There is no comparison on the length of time covered and intensity of service before and after commitment.

Before commitment, 10 of the 13 children who received psychiatric service were known to the Mental Hjgiene clinic, while 6 children were known to the Louisvilie General Hospital 
Department of Psychiatry. Only l child was seen by the agency poychiatrist.

Following commitment, more children were seen by the Louisville and Jefferson County Children's Home psychiatrist than by the Mental Hygiene clinie and Louisville General Hospital Department of Paychiatry together. of the 20 children who received pajehiatric service after becoming wards of the ageney, 18 were seen by the agency paychiatrist, 7 were known to Louisville General Hospital Department of Psychiatry, and only 1 was referred to the Mental Hygiene clinic.

This analysis shows that 5 of the 28 children received no psychiatric service at all during the timo preceding their commitment and during their commitment.

It would seem, then, that a mental bygieno program of asistance for these children with their problems has played an important part in their adustment. There were no norms by which to measure success or failure. The writer received the impression, however, that there was some progress in a considerable number of cases. Even in cases where the child went on to further antisocial beharior, as in the case 1

of Harold, the agency paychiatrist thought there had boen improvement and some progress indicated.

\section{Children known to other Institutions}

Table 13 shows the number of children who were known to institutions before their commitment to the Louisvillo and

Supra, pp. 62-63. 


\section{TABLE 13}

CHILDREN KNOWN TO OTHER INSTITUTIONS BEFORE AND AFTER COMMITHENT TO LOUISVIILE AND JEFFERS ON COUNTY CHILDREN'S HONE

\begin{tabular}{|c|c|c|}
\hline Institutions & $\begin{array}{c}\text { Before } \\
\text { Commitment }\end{array}$ & $\begin{array}{c}\text { After } \\
\text { Commitment }\end{array}$ \\
\hline $\begin{array}{l}\text { Kentucky Children's Home } \\
\text { St. Joseph's Orphanago } \\
\text { St. Thomas Orphanage } \\
\text { Maryhurst } \\
\text { Central State Hospltal } \\
\text { Kentucky Houses of Reform } \\
\text { Kentucky Training school } \\
\text { Bellefair School (Cincinnati, Ohio) } \\
\text { Stuart Robinson school (Blakey, } \\
\text { Kentucky) } \\
\text { Total }\end{array}$ & $\begin{array}{l}2 \\
1 \\
1 \\
2 \\
1 \\
- \\
- \\
1 \\
-\end{array}$ & $\begin{array}{l}- \\
- \\
- \\
- \\
4 \\
4 \\
1 \\
- \\
1\end{array}$ \\
\hline
\end{tabular}

Jefferson County Chilaren's Home as well as the number known to institutions after their commitment to the ageney. From this presentation it can be seen that the commitment to Louisville and Jefferson County Children's Home was not the first institutional experience for 8 or the 28 children. The question may be raised as to the social adjustment made by these children in their first institutional setting. Without exception, the records revealed that all 8 had made an unsatisfactory social adustment in the previous institution. Ten children were known to other institutions following their commitment to the agency. The figures shown in Table 13, however, cover 15 different children. In other words, 3 children were known to two other institutions and 12 
children were known to one other institution. The types of institutions which knew these children are revealed by the names of the institutions. The last two named are private boarding schools.

Eight of the 10 children known to other institutions after their commitment to the Louisville and Jefterson County Children's Home were known to Central State Hospital and Kentucky Houses of Reform. One child was known to Kentucky Training school. At this point, it should be mentioned that another child was committed to the Kentucky Training school, but due to crowded conditions she has never been entered there. She is still a ward of the Louisville and Jetterson County Children's Home and is not included in tigures in Iable 13.

\section{Disposition upon Release rrom the Louisville and Jetierson County Children's Home}

Fourteen of the 28 children were released from the supervision of the agency at the time or the stuay. It is interesting to see the immediate disposition upon release of these 14 children. Ihis is shown in Table 14.

The child who was released to the Jurenile court with a recommendation of commitment to the Kentucky Eouses of Reform was subsequently committed there by the court. One child released to his parents, or Home, was later committed by the Juvenile Court to the Kentucky Houses of Reform.

The 2 children whose disposition was "Other" were released following the receipt of pertinent information regarding 


\section{T'ABLE 14}

\section{DISPOSITION OF FOURTEEN CHIIDREN UPON RELEASE \\ FRON TEE LOUISVIILE AND JEFEERSON COUNTY CEILDRTN'S HONE}

$\begin{array}{lc}\text { Disposition upon Release } & \text { Mumber Rel } \\ \text { Central State Hospital } & 4 \\ \text { Kentucky Fouses of Reform } & 2 \\ \text { Kentucky Training School } & 1 \\ \text { Home } & 4 \\ \text { Juvenile Court } & 1^{a} \\ \text { Other } & 2^{b}\end{array}$

areleased to Juvenile court with a recommendation of commitment to Kentucky Eouses or Reform. b

one child was killed while absent from home, thus released. The second child had been absent six months; following receipt of an unconfirmed report that he was working outside Jefferson County and living with his foster mother, he was released.

them after prolonged unauthorized absences. One child had been absent from home for four months; no word was received by the agency or his family until they learned of his death in an automobile accident in a southwestern state. The second child had been absent from Ridgewood for six months. Following receipt of an unconfirmed report that he was working outside Jefferson county and living with the foster mother who had reared him, he was released by the agency.

The number ot children released to central state Hospital seems significant. The 4 children who were committed there carried a diagnosis of epilepsy; 3 of them had nbehavior disorder" as a part of their diagnosis; the other 1 was released with a diagnosis of epilepsy with psychosis. It 
73

appeared that these children were unable to adjust in the

community and in the institution. Since it was not con-

sidered safe for the other children at the village to be

subjected to their acts, they were sent to an institution

for the mentally ill as a last resort. There was no other

resource available for them in the state. Inquiry was made

by the social worker about the possibility of admitting 1

child, David, to the Indiana Village tor Epileptics. It was

not possible, however, for the state of Indiana to admit a

child from the state or Kentucky.

One of the 4 children released to the home was later

committed by the Juvenile Court to the Kentucky Houses of

Reform. 


\section{CHAPTER $\nabla$}

\section{SUMMARY AND CONCLUSIONS}




\section{CHAPTER V}

\section{SUMMARY AND CONCLUSIONS \\ Summary}

The purpose of the study was to understand the sociel adjustment of epileptic children and those with a predisposition to convulsions in the Louisville and Jefferson County Children's Home. Analysis was made of the characteristics of the group and how they adjusted--what their problems were before commitment and how they were handled, what their problems were after commitment to the agency and how these were met, and the disposition upon release from the agency. The group included 28 children, of which 23 were males and 5 were females; 22 were white and 6 were negro; 16 were committed for dependency and 12 for delinquency; 22 came from broken homes. The majority were committed during adolescence.

As to level of intelligence, 1 child was of superior intelligence, 10 were average, 9 were dull normal, 6 were borderline, and 2 were mentally defective. This distribution was similar to that of the Louisville and Jefferson county Children's Home population. Psychological tests showed that they achieved on a par and below their ability. Nine were placed in school above this achievement; 5 were assigned to special classes; and 4 did not attend school. Children did 
not attend school due to unauthorized absences and detention in the lock-up and the children's center in the greatest number of cases. The group had many admissions to the Children's center, both before and after commitment to the agency, for reasons of unauthorized absence, transfer of placement, and study purposes, with absences leading. The majority or the children had siblings in their families; 8 showed a history or seizures in other members of the family. Medical diagnoses were grouped into four clasifications: epilepsy, borderline opilepsy, predisposition to epilepsy, and possible epileptio seizure which were nerer diagnosed as epilepsy. There seomed evidence of some reluctance on the part of the medical profession to give a definite diagnosis or epilepay, due possibly to the stigme it carried. sixteen of the children were committed to the agency during the adolescent years. Four children had seizures during the first two years or life and 4 at the age or eight. Twentytwo of the children were committed after the onset of seizures and beharior problems.

The Medical Department prescribed the usual medications used for this condition. There was an attempt to secure the proper medication for each child by change of prescription when the situation warranted it. Twenty-four children received medication. There was good control of seizures and behavior in 5 cases, fair control in 8 cases, and poor control in 6 cases. 
The most common problems of the children before commitment were stealing, truancy from school, absence rrom home, enuresis, and inability to get along with other children. The Jurenile court handled many of these children, and some were placed in other institutions. Parents seemed ineprectual and unable to cope with the situation.

During commitment, the largest number of problems of the children were unauthorized absence, aggression, attention getting, withdrawal, shame, and resentment. All but 4 children had unauthorized absences. One child had as high as twenty-two absences. Some absences were of short auration, and some were soveral months long.

Rejection or the chila by the ramily, especially on the part of the mother, was present in 22 cases. Also, orerprotection, worry, misunderstanding, and non-acceptance were common. The utitudes of start members of the institution and agency were helpful and understanding. They showed extreme patience, interest, and sympathy. The children in the institution, however, disliked and "picked on" the epileptics frequently.

The lock-up was rrequently used as a ncooling ort" place atter unauthorized absences. Since this group had many unauthorized absences, they were otten placed there. The status of the child in the institution was frequently reduced. Every child had a social worker who kept contact with him during his entire period of commitment. Psychiatric 
service was given in 20 cases atter commitment. The ageney paychiatrist worked with 18 of them. Seven of the children were referred to Louisville General Hospital Department or Poychiatry during thoir commitment and 1 to Montal Hygiene CIInic.

Fifteen of the chilaren were known to other institutions, either before or efter commitment; 3 of these were known to two other institutions, and 12 were known to one other institution.

Fourteen children in the group were released by the ageney. One was released to the Jurenile court with a recommendation of commitment to Kentucky Houses of Reform, which was effected. Four were released to central state Hospital, 2 to Kentucky Houses of Reform, and l to Kentucky Training school. Four were released to their home. One of the latter was later committed by the Jurenile Court to the Kentucky Houses of Reform.

\section{Conclustons}

The study has pointed out that children with epileptic seizures and a predisposition to convulaions have many problems. Many ware committed to the Louisville and Jefferson County Children's Home because there was no other place for them to go. After commitment, it was difficult to find foster homes for those with seizures and difficult personality problems. Those who had placements in their own homes often returned to an 
environment fraught with the same stresses and strains which proved difficult before. The Louisville and Jefferson County Children's Home offered the children the best service which was available.

Howerer, it would seom that these handicapped children need a secialized institution when institutional care has been indicated. The writer feels that an epileptic colony or paychiatric hospital for children would benefit this type of child because there he would be fully accepted by all without reservation due to the physical condition. Kentucky has nothing of this sort to offer the child who must be institutionalized. More specifically, the study revealed a common symptom of running away erom the reality situation. It would sem that some further exploration might be indicated in this area with the hope of resultant recommendations around the problem.

A well-rounded mental hygiene program is needed wherein the child as a whole is considered. Psychotherapy and caso work service seom indicated. The child needs to be kept busy and to feel useful and happy. occupational therapy and rocational training are important phases of any treatment and care program. There is a great need for further education and publicity around epilepsy. Not only must the epileptic be educated as to his condition, but also the professional groups and the general population must be better intormed in order to relieve the misunderstanding, shame, and stigma attached to it. 
There is hope for a tull and satisfying life for most epileptics if they can learn to accept their condition and its limitations and be accepted by their friends and associates. Groups, such as the Health and Welfare Council of the Louisville Community chest, which are showing interest in the epileptic child, are a promising move in that direction. 
APPENDIX 


\section{RESUITS OF INTER-AGENCY COMNITTEE QUESTIONNAIRE ON EPILEPTICS AS OF JUIY 1,1947}

Health and Welfare Council, Louisville Community chest

Agency

Individual Cases

Ald to Dependent Families Dirision . . . . . . . 9

American Red Cross... . . . . . . . . . . . . 1

Children's Agency . . . . . . . . . . . . . . . 3

Children's Hospital . . . . . . . . . . . . . -

Division of Public Assistance (state) . . . . . . 26

Family service organization . . . . . . . . . 4

Goodwill Industries . . . . . . . . . . . . . . 1

Jefferson County Welfare Department . . . . . . . *

Jewish Vocational Service . . . . . . . . . . . . -

Jewish Welfare Federation . . . . . . . . . . . . -

Juvenile Court. . . . . . . . . . . . . . . 3

Kentucky Children's Home . . . . . . . . . . . . -

Kentucky Crippled Children's Commission . . . . . 3

Kentucky State Employment Service . . . . . . . . 6

Louisville Baptist Orphans' Home . . . . . . . . . -

Louisville and Jef'terson County Children's Home . . 13

Louisilie and Jefferson County Health Department. .

Nedical Social Service Department . . . . . . . . **

Louistille Public Schools . . . . . . . . . . . *

Mental Hygiene Clinic.. . . . . . . . . . . . . -

Municipal Bureau of Social Service... . . . . . 7

Nichols General Hospital. . . . . . . . . . . 12

St. Joseph's Orphans' Home . . . . . . . . . . -

St. Thomas Orphanage . . . . . . . . . . . . . . . -

St. Vincent orphanage . . . . . . . . . . . . . . . 2

Sisters of the Good Shepherd.............. -

State Vocational Rehabilitation Department. . . . . 8

Synodical Presbyterian Orphanage . . . . . . . . . *

Veterans Administration . . . . . . . . . . . 5

Visiting Nurse Association... . . . . . . . . . -

* Did not return questionnaire

Gave figures for year 1946, not specitic date 


\section{APPENDIX B}

INSTITUTIONS SURVEYED FOR EPILEPTIC CHILDREN, DECEMBER, 1947

Central State Hospital

Christian Church idows and Orphans Home

Good Shepherd Home ror Colored Girls

Kentucky Children's Home

King's Daughters Home for Incurables

Louisville and Jefferson County Children's Home

Maryhurst school - Sisters of the Good Shepherd

Masonic Widows and Orphens Home and Intirmary

Our Lady's Home for Intants

Protestant Orphans Home

St. Joseph's Orphans Home

St. I'homas Orphanage

st. Vincent orphanage

spring Meadows (formerly Louisville Baptist Orphans Home)

Synodical Presbyterian Orphanage

Woodcock Hall 
2. Vnit No. 20 Kame 3. Ago (ofrth dato)

4t: $89 x$

5. Color

6. a. Institution

b. Datea

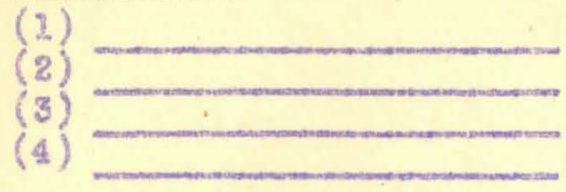

(1) รxom
O. Age ตt commat

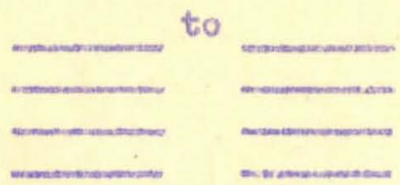

(1)

(2)

(3)

(4)

7. Reason comalttid

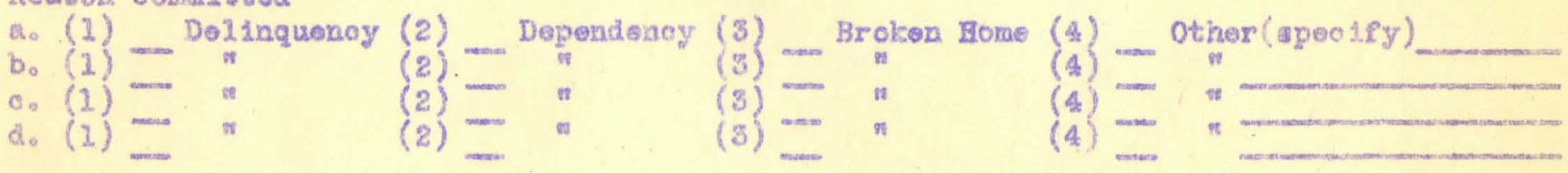

8. so Onast salauras (date) b. Age :

9. 20. Date diagaosis b. Age

10. Typo

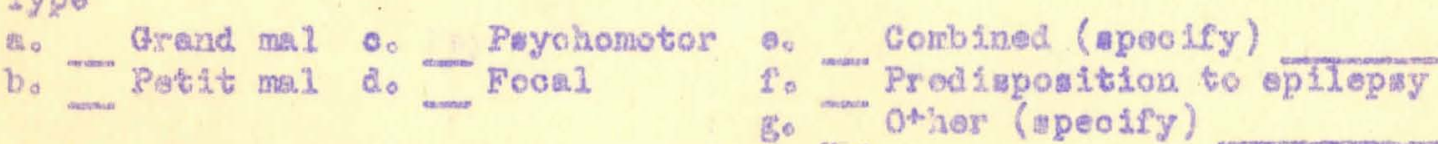

3.1. Frequency

12. EBG Imprearion \& data

15. Modiostion

a. Phenoberbital d. Phonobarb s dilantin

b. Dilantin

o. Phenoberb, dilentin stidione ho -

0.

f. Pheno, dil, trid, beneidrene 1. -

14. Control

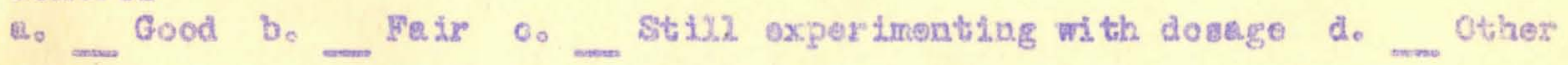

15. Ragulstion or treatment

6. Reguls medion supervis ion

b. Frequent mod loal mupervision

co Sporad lo modioal supervi sion

d. - No supervision present time

4. Inknowa

2. 2. Moxtal devolopment

(1) Levol of Intelifigenoe

(2) $\mathrm{se}$

b. School

(1) Grade

(2) Non-attendenos

(5) Resacn 
17. 2. Bohavlor bofore irescituibtona11zed
(2)
(2)
(3)
(4)

Elor handi.ol

(i)

(2)

(4)

18. Adjustonent to 2.22ns s:

a. Soclo-oconomio problems
(1) Pinanoiol
(2) Vocationes?
(3) School
(4) - Panily relations: (ai) mother-fethor (b) $=$ pureatioshild

(5) $\operatorname{Other}$ (spostfy)

b. Physicai probleng

(1)

(3)

$\left(\begin{array}{l}2) \\ 4\end{array}\right.$

0. Emotional problews

(1) Attitudeis of child in ingtitution
(a) aoseptaros (e)
withil $x$ ewal $(\mathrm{s})$

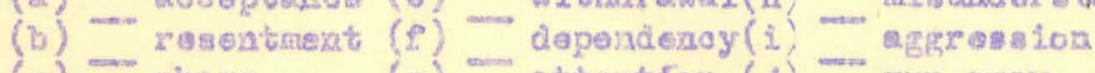
(c) misams
(d) $=$ uneshaned
$(\mathrm{g})=$ attonton $(\mathrm{J})$
(J) $=$ rus was
getiting
(i) $\ldots$ foll a different

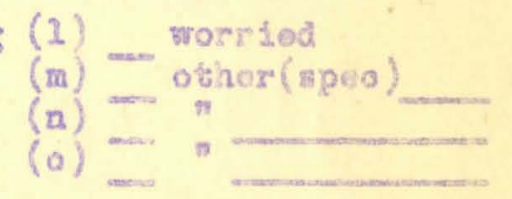

(2) Attitudea of ots1a"s fam $12 y$

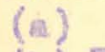 accoptance $(\theta)=$
over protection (i.)
(b) - xaenntment (f) rejoction
(c) anamo
(d) $\ldots$ mras shamed
(b)
rojection
(j) - hor $^{\text {(1) }}$ wory
miausderstand ing $(1)$
(k) $=$ othsr (apoo)
a Igraranco
(in)
ต

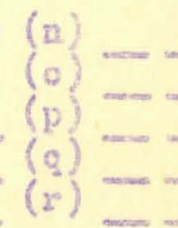

(3) Attitudea shown by otkarg in tastitution

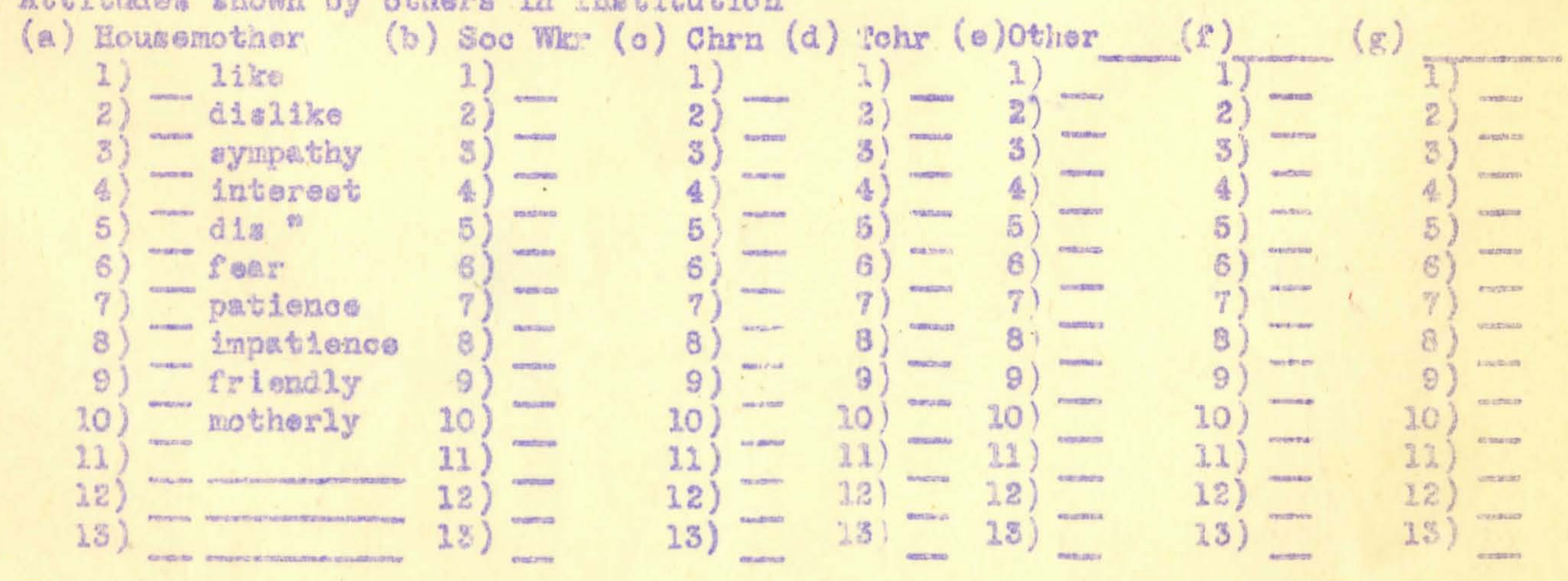

(4) How hendled in ingtitution
(a) Lockup
(b) Sent LGR-D?
(c) Chango envir onuant
$(\mathrm{g}), \ldots$
DLs ob arge
(k) Mod1oal oare
(d) Teolaticn
(e) - Igroral
(i) $=$ Sympetity

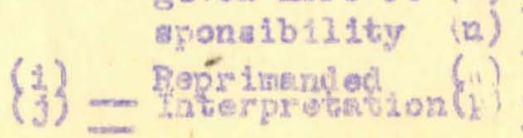


19. Intereatis of ohile
a. Voeationasi.
b. Hobbion \& Rooreation
(1)
(3)
(3)
a. Sohool
$\left\{\begin{array}{l}1 \\ 2\end{array}\right)$
d. Inatitutional bore 2 ifs (2)
(1)
a. Others
s. "
(1)
B.
$(1)$

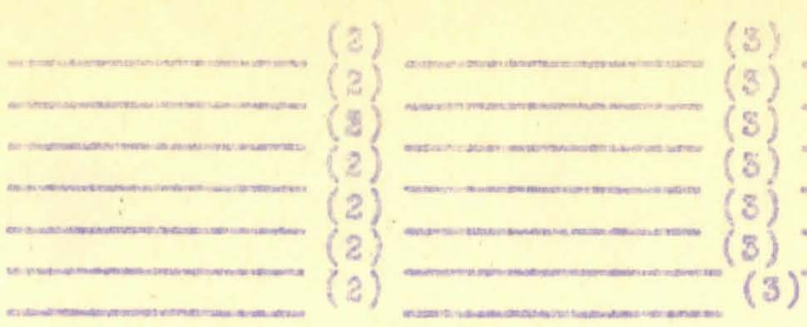
(3)
(3)
(8)
3)
(3)

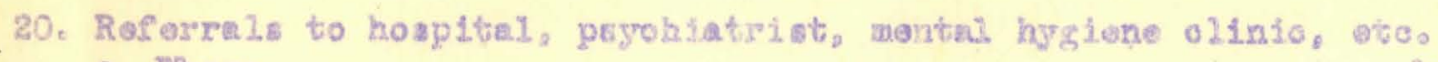
a. Where
(1)
(2)
(3)
(4)

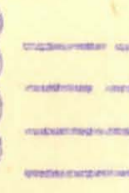

perobiatipisti

011010, 060

O. Theis reoord
(1)
(2)
(3)
a. Dinte日
(2)
$(2)$
$(3)$
$(4)$
d. Reason
(5) 1 -

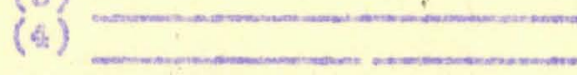

C. Manultu
(1.)
(2)
(s)
(4)

21. S1blings and ohild"g relationship thereto

23. Panily Elatosy

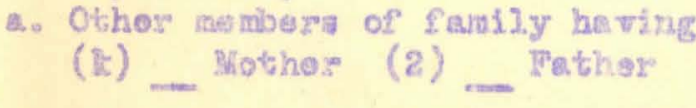
(\$)
Bres

athor peribinont forte

23. Discharga from inetitution

b. Datse

o. Whare

d. Rosson

24.

Resis

25.

$2 \mathrm{~S}^{\circ}$ 
RESOURCES OF PSYCHIATRIC SERVICES USED BEFORE AND AFTER COMMITMENT

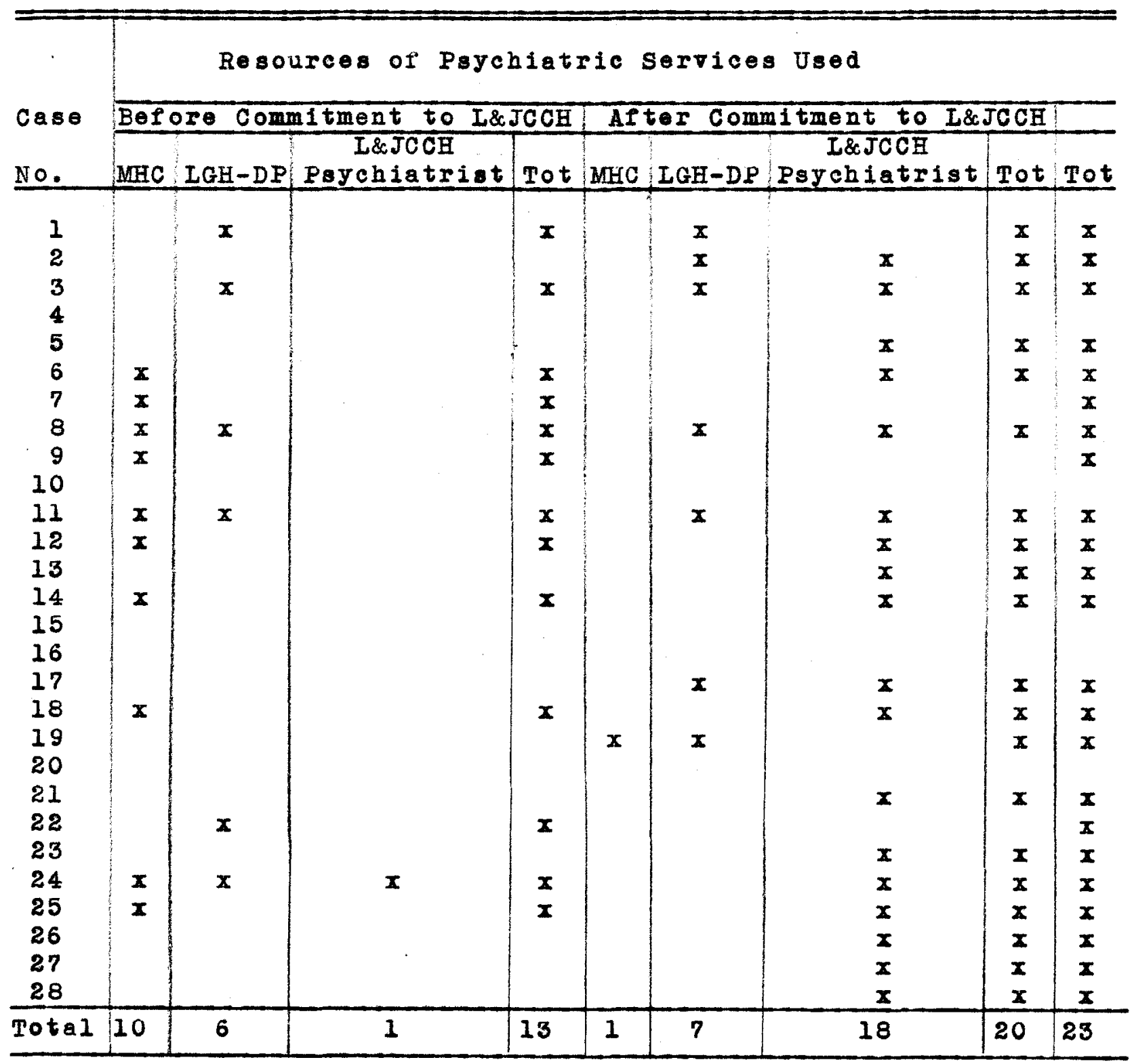

MHC - Mental Hygiene Clinie

LGH-DP - Louisville General Hospital Department of Psychiatry I\&JCCH - Louisville and Jefferson County Children's Home 
BIBLIOGRAPHY 


\section{BIBL I OGRA PHY}

\section{Books and Pamphlets}

Bastin, Henley $V$. Institutions as Treatment centers. A Paper read at The National Conference of Juvenile Agencies, Toronto, Canada, September 19, 1929. Anchorage, Kentucky: Ormsby Village Press, 1929.

Bradley, Charles. Management of the Convulsive Child. Boston: American Epilepsy League, Inc., 1946.

Challenge and Action. Progress Report 1944-1946 of National Association to Control Epilepsy, Inc. New York:

National Association to Control Epilepsy, Inc., 1947.

The Epileptic Child in Illinois. Illinois commission for Handicapped Children, June, 1945.

The Green Light. Vol. 2, No. 3. New York: National Association to Control Epilepsy, Inc., April, 1947.

Iennox, William G. The Epileptic-Who He Is--What He Can Do. Boston: American Epilepsy League, Inc., 1945. - The Epileptic Patient and the Nurse. Boston: American Epilepsy Ieague, Inc., 1946 .

- Marriage and Children for Epileptics. Pamphlet reprinted from Journal of Human Fertility, $X, N o .4$ (December, 1945T.

- Science and Seizures. 2d Ed. New York: Harper and Bros., 1946.

Merrit, H. Houston. Treatment of Epilepsy. Boston: American Epilepsy League, Ine., 1946.

Pinanski, Joan. Social Service and Seizures. Chicago: American Epilepsy League, Inc., 1946.

Potter, Mrs. Brooks. Building a Future for the Epileptic Child. Boston: American Epilepsy League, Inc., 1945.

Price, Jerry C. Epilepsy--What Can Be Done About It? New York: National Association to Control Epilepsy, Inc., 1946. 
Putnam, Tracy J. On Convulsive seizures, a Manual for Patients. New York: J. B. Lippincott Co., 1943.

Teagarden, Florence. Child Psychology for Professional Workers. Rev. ed. New York: Prentice-Hall, Inc., 1946 .

Weber, Margaretta. Working with Dependent and Delinguent Children in the same Ingtitution. Anchorage, Kentucky: Ormsby Village Press, 1935.

Yahraes, Herbert. Woman Without Fear. Boston: American Epilepвy League, Inc., 1945.

- Epilepsy--The Ghost is out of the closet. Public Affairs Pamphlet. No. 98. New York: Public Affairs Committee, Inc., 1944.

\section{Articles}

"Aid for Epileptics," Time, XIVII (June 10, 1946), 48.

Bradiey, Charles. Nreatment of the Convulsive child in a Children'a Psychiatric Hospital," The Nervous Child, VI, No. 1 (January, 1947), 76-85.

Carter, James D. "Children's Ixpressed Attitudes Toward Their Epilepsy," The Nerrous Child, VI, No. 1 ( January, 1947), 34-37.

Collins, A. Louise. "Psychometric Records or Ingtitutionalized Epileptics," Journal of Psychology, XI (April, 1941), 359-370.

Daridoft, Eugene. "Treatment of Institutionalized Epileptic Children," The Nervous Child, VI, No. I (January, 1947), 57-75.

Dixon, R. I. "State Hospital School for Epileptic children," The American Journal of Psychiatry, CIII, No. 6 (May, 1947), 811-81\%.

Elckhorf, Louise F. W., and Beerers, C. A. "The Electroencephalogram in Maladjusted Children," The American Journal of Paychiatry, XIV, No. 3 (september, 1947), 194-196.

"Epilepsy," Iffe, XX (June 3, 1946), 129-130. 
"Epilepsy Remedy Controls Abnormal Behavior As Well," Seience Newe Letter, XIIX (March 9, 1946), 152.

Fishbein, M. "Nervous and Convulsire Disorders in Children," American Home, XXXVII (December, 1946), 79-80.

Jensen, Reynold A. The Importance of the Emotional Factor in the Convulsive Disorders of Children," American Journal of Psychiatry, CIV, No. 2 (August, 1947), 126-131.

"New Better Epilepsy Medicines Coming," Science News Letter, I (July 27, 1946), 52 .

Price, Jerry. "The Approach to Providing services to the Epileptic," Journal or Rehabilitation (October, 1946 ).

Price, Jerry C. and Otto, Johin I. Standard Treatment of Epilepay. Reprinted from Diseases of the Nervous System, VII, No. 11 (November, 1946).

Price, Jerry, and Putnam, Tracy J. "The Effect of Intrafamily Discord on the Prognosis or Epilepsy," American Journal of Psychiatry, C (March, 1944), 593-598.

Silverman, Milton. We can Iick Epilepsy," Saturday evening Post (January 17,1948 ).

Yahraes, Herbert. "New Hope for Epileptics," American Mercury, IXI (July, 1945), 50-54.

\section{Unpublished Material}

Sherrill, Helen H. "Changing Philosophy or Child care in the Louistille and Jerterson County Children's Home A8541943)." Onpublished Master's thesis, Graduate Division or Social Administration, University or Louisilile, 1944 .

\section{Miscellaneous}

Klinger, Pauline. Second Annual Report, Psychology Department, Louisrille and Jefrerson County Children's Home, July 1 , 1944-Ju1y I, 1945. 
Mecarley, Elizabeth. Mclassitication of Intelligenco According to Test perrormances," Memorandum of the Paychology Department, Louistille and Jerterson County Children'B Home, December 12, 1947.

Minutes, Inter-Agency Committee and its sub-Committer, Health and Welfare Couneil, Louisville Community Chest, July 1, 1947 through October $20,1947$. 